\title{
Synthesis, characterisation, and in vitro cellular uptake kinetics of nanoprecipitated poly(2-methacryloyloxyethyl phosphorylcholine)-b-poly(2-(diisopropylamino)ethyl methacrylate) (MPC-DPA) polymeric nanoparticle micelles for nanomedicine applications
}

\author{
Jonathan P. Salvage ${ }^{1} \cdot$ Tia Smith $^{1} \cdot$ Tao Lu $^{1} \cdot$ Amendeep Sanghera $^{1} \cdot$ \\ Guy Standen ${ }^{1} \cdot$ Yiqing Tang ${ }^{2} \cdot$ Andrew L. Lewis ${ }^{2}$ \\ Received: 4 January 2016/Accepted: 12 January 2016/Published online: 23 January 2016 \\ (c) The Author(s) 2016. This article is published with open access at Springerlink.com
}

\begin{abstract}
Nanoscience offers the potential for great advances in medical technology and therapies in the form of nanomedicine. As such, developing controllable, predictable, and effective, nanoparticle-based therapeutic systems remains a significant challenge. Many polymerbased nanoparticle systems have been reported to date, but few harness materials with accepted biocompatibility. Phosphorylcholine (PC) based biomimetic materials have a long history of successful translation into effective commercial medical technologies. This study investigated the synthesis, characterisation, nanoprecipitation, and in vitro cellular uptake kinetics of PC-based polymeric nanoparticle micelles (PNM) formed by the biocompatible and $\mathrm{pH}$ responsive block copolymer poly(2-methacryloyloxyethyl phosphorylcholine)- $b$-poly(2-(diisopropylamino)ethyl methacrylate) (MPC-DPA). Atom transfer radical polymerisation (ATRP), and gel permeation chromatography (GPC) were used to synthesise and characterise the welldefined $\mathrm{MPC}_{100}-\mathrm{DPA}_{100}$ polymer, revealing organic GPC, using evaporative light scatter detection, to be more accurate than aqueous GPC for this application. Subsequent nanoprecipitation investigations utilising photon correlation spectroscopy (PCS) revealed PNM size increased with polymer concentration, and conferred Cryostability. PNM diameters ranged from circa 64-69 nm, and
\end{abstract}

Jonathan P. Salvage

J.P.Salvage@brighton.ac.uk

1 School of Pharmacy and Biomolecular Sciences, University of Brighton, Huxley Building, Lewes Road, Brighton BN2 4GJ, UK

2 Biocompatibles UK Ltd, a BTG International plc Group Company, Innovation Group, Lakeview, Riverside Way, Watchmoor Park, Camberley GU15 3YL, UK increased upon hydrophobic compound loading, circa $65-71 \mathrm{~nm}$, with loading efficiencies of circa $60 \%$ achieved, whilst remaining monodisperse. In vitro studies demonstrated that the PNM were of low cellular toxicity, with colony formation and MTT assays, utilising V79 and $3 \mathrm{~T} 3$ cells, yielding comparable results. Investigation of the in vitro cellular uptake kinetics revealed rapid, $1 \mathrm{~h}$, cellular uptake of $\mathrm{MPC}_{100}-\mathrm{DPA}_{100}$ PNM delivered fluorescent probes, with fluorescence persistence for $48 \mathrm{~h}$. This paper presents the first report of these novel findings, which highlight the potential of the system for nanomedicine application development.

Keywords Nanomedicine - Phosphorylcholine - MPCDPA $\cdot$ Micelle $\cdot$ Nanoparticle $\cdot$ Drug delivery

\section{Introduction}

Recent estimates place the annual global incidence of, and mortality from, human cancers at circa 14 and 8 million cases per annum and growing (Torre et al. 2015). This is clearly a significant societal burden and challenge, which must be overcome for both humanitarian and financial reasons. The advent of nanotechnology-enabled medical therapies, termed nanomedicines (Farokhzad and Langer 2006; Sahoo et al. 2007), offers the potential for great advances in the development of novel anti-cancer treatments (Kawasaki and Player 2005), with one of the main areas of research being stimuli-responsive polymeric nanoparticle-based nanomedicines (Crucho 2015). As part of that research and development momentum, elucidating the cellular uptake kinetics of nanoparticles is critical for developing a greater understanding of nanoparticulatebased intracellular delivery systems (NIDS) that utilise 
endocytosis for therapeutic delivery via cell membrane transport (Sahay et al. 2010) in an active and applied manner. Phosphorylcholine (PC) based polymers (Hayward and Chapman 1984) have a successful record of innovative biomaterials development and application (Lewis 2000), including biocompatible $\mathrm{pH}$ responsive polymeric NIDS (Salvage et al. 2005). As such a number of studies have explored the in vitro cellular uptake of $\mathrm{pH}$ responsive poly(2-methacryloyloxyethyl phosphorylcholine)- $b$ poly(2-(diisopropylamino)ethyl methacrylate) (MPC-DPA) block copolymer nanoparticles (Lomas et al. 2008; Massignani et al. 2010) which have demonstrated the potential for therapeutic delivery (Colley et al. 2014), but have been primarily concerned with polymersome, vesiclebased, systems of circa $100 \mathrm{~nm}$ or greater diameter. However, to date, the smaller diameter micelle-based MPC-DPA nanoparticle systems have attracted less attention, with studies focused primarily on achieving delivery (Licciardi et al. 2008; Yu et al. 2013), without fully considering the kinetic aspects of the cellular uptake reported. The small size of micelles has advantages, as it may facilitate particle accessibility to systemic locations not accessible to larger sized delivery vehicles (Singh and Lillard 2009). Since the first reports of MPC-DPA polymers (Ma et al. 2003) and nanoparticles (Salvage et al. 2005; Licciardi et al. 2005), the systems have remained considerably less well characterised than their extensively studied alternatives, such as PEG-based nanosystems (Torchilin 2002; Shiraishi et al. 2009; Locatelli and Franchini 2012; Logie et al. 2014; Laskar et al. 2015). MPCbased polymers are thought to possess improved antifouling properties (Lewis 2000) in comparison to PEG-based polymers due to the greater level of hydration reported for MPC, circa 23 water molecules per MPC unit (Goda et al. 2006; Morisaku et al. 2008), in contrast to circa 3 per PEG unit (Maxfield and Shepherd 1975; Shikata et al. 2006). The premise of these biomimetic NIDS being the ability to avoid reticuloendothelial system (RES) clearance (Gref et al. 1994), more so if within the 30-100 nm particle diameter size range (Garcia et al. 2014), and thus attain sufficiently long systemic circulatory times such that they can harness the enhanced permeability and retention (EPR) effect (Maeda 2001) in order accumulate at tumour sites due to the abnormally leaky vasculature (Takakura et al. 1998; Ho and Shoichet 2013). In the case of pH-responsive MPC-DPA (Ma et al. 2003; Salvage et al. 2005), the PNM would then release the therapeutic cargo in response to the lowered $\mathrm{pH}$ environment found in endosomes (Sharma and Sharma 1997) and tumour tissue (Liu et al. 2014).

It has been previously reported that MPC-DPA diblock copolymers form monodisperse polymeric nanoparticle micelles (PNM) via nanoprecipitation (Salvage et al. 2015). This current paper expands upon the previous work, examining the synthesis and characterisation of the diblock copolymer $\mathrm{MPC}_{100}-\mathrm{DPA}_{100}$, followed by a further exploration of the polymer with regard to the nanoprecipitation parameters of polymer concentration, solvent to non-solvent volume ratio, model drug compound loading, and the effect of these on particle size and polydispersity, followed by an investigation of in vitro cellular uptake and delivery. This paper reports for the first time novel data and findings regarding $\mathrm{MPC}_{100}-\mathrm{DPA}_{100} \mathrm{PNM}$ formation, stability, loading, and intracellular uptake kinetics, which aids to further the understanding of applied endocytosis, for these PC-based PNM systems to be harnessed for effective intracellular delivery applications, and potentially nanomedicine.

\section{Materials and methods}

\section{Synthesis and characterisation of $\mathrm{MPC}_{100}-\mathrm{DPA}_{100}$ block copolymer}

The $\mathrm{MPC}_{100}-\mathrm{DPA}_{100}$ diblock copolymer was synthesised via atom transfer radical polymerisation (ATRP) in methanol $(\mathrm{MeOH})$ at ambient room temperature, having adapted a published ATRP method (Ma et al. 2003) by utilising 2-(4-morpholino)ethyl 2-bromosiobutyrate $(\mathrm{MEBr})$ as the initiator, at [MPC]:[MEBr]:[CuBr]:[Bpy]:[DPA $]=100: 1: 1: 2: 100$ relative molar ratios. The MEBr was synthesised and purified according to a literature protocol (Bories-Azeau et al. 2004), and confirmed by ${ }^{1} \mathrm{H}$ nuclear magnetic resonance (NMR) analysis. The resultant MPC-DPA copolymer was characterised for molecular weight ( $\mathrm{Mw}$ and $\mathrm{Mn}$ ) and polydispersity (Mw/ Mn) via ${ }^{1} \mathrm{H}$ NMR and gel permeation chromatography (GPC). ${ }^{1} \mathrm{H}$ NMR was undertaken with a Bruker Ascend ${ }^{\mathrm{TM}}$ $400 \mathrm{MHz}$ spectrometer, 16 scans per spectrum, using chloroform-d $\left(\mathrm{CDCl}_{3}\right)$ and methanol- $\mathrm{d}_{4}\left(\mathrm{CD}_{3} \mathrm{OD}\right)$ NMR solvents (Sigma, UK) at a 3:1 (v/v) ratio (Pearson et al. 2013); the $\mathrm{CDCl}_{3}$ contained $1 \%$ (v/v) tetramethylsilane (TMS) as an internal standard ( $\mathrm{Li}$ et al. 2004). GPC analysis was undertaken using both organic and aqueous mobile phase and column types to evaluate their comparative suitability and accuracy. The organic GPC system utilised Phenogel ${ }^{\mathrm{TM}} 5 \mu \mathrm{m} 10^{4} \AA$ and $5 \mu \mathrm{m} 10^{3} \AA$ columns $(300 \mathrm{~mm} \times 7.8 \mathrm{~mm})($ Phenomenex, UK) in series, and a Polymer Labs (PL-ELS-2100 Ice) evaporative light scatter (ELS) detector $\left(45^{\circ} \mathrm{C}\right.$ nebuliser and evaporator, $1.11 \mathrm{~min}^{-1}$ nitrogen flow). The organic mobile phase eluent was chloroform $\left(\mathrm{CHCl}_{3}\right)$ : $\mathrm{MeOH}(3: 1 \mathrm{v} / \mathrm{v})$ (Fisher, UK), containing $0.1 \%$ acetic acid (AcAc) and $0.05 \%$ trifluoroacetic acid (TFA) (Sigma, UK), with a flow rate of $1.0 \mathrm{ml} \mathrm{min}{ }^{-1}$ at $45^{\circ} \mathrm{C}$, and a sample injection volume of $5 \mu \mathrm{l}$ at $1 \mathrm{mg} \mathrm{ml}^{-1}$. The aqueous GPC system utilised 
BioSep ${ }^{\text {TM }}$ SEC-s3000 $5 \mu \mathrm{m}$ and SEC-s2000 $5 \mu \mathrm{m}$ columns (300 mm x $7.8 \mathrm{~mm}$ ) (Phenomenex, UK) in series, and a Shodex (RI-101) refractive index (RI) detector. The aqueous mobile phase eluent was $0.5 \mathrm{M}$ acetate buffer $(\mathrm{pH}$ 2) (Sigma, UK), with a flow rate of $0.5 \mathrm{ml} \mathrm{min}-1$ at $40{ }^{\circ} \mathrm{C}$, and a sample injection volume of $30 \mu \mathrm{l}$ at $10 \mathrm{mg} \mathrm{ml}^{-1}$. A series of near monodisperse polyethylene glycol (PEG) and polyethylene oxide (PEO) GPC standards (Crawford Scientific, UK) were used for GPC calibration.

\section{Preparation of $\mathrm{MPC}_{100}-\mathrm{DPA}_{100}$ polymeric nanoparticle micelle systems}

The $\mathrm{MPC}_{100}-\mathrm{DPA}_{100}$ PNM systems were prepared using a previously reported nanoprecipitation method (Salvage et al. 2015), utilising methanol (MeOH) (Fisher, UK) and phosphate buffer saline (PBS) (Oxoid, UK) as the solvent and the non-solvent phases, respectively.

\section{Polymer concentration, freeze-thaw, and freeze-dry rehydrate effect}

Solutions of the $\mathrm{MPC}_{100}-\mathrm{DPA}_{100}$ copolymer $\left(40 \mathrm{mg} \mathrm{ml}^{-1}\right.$ ) were prepared in $\mathrm{MeOH}$, and aliquots (100, 200, 300, 400, and $500 \mu \mathrm{l}$ ) of these solutions were added drop-wise to 9.9, 9.8, 9.7, 9.6, and 9.5 $\mathrm{ml}$ of PBS, $\mathrm{pH} 7.4$, respectively. The resultant samples were $0.22 \mu \mathrm{m}$ pore size syringe filtered (Millipore, UK), each sample was divided into 3 equal volumes, and these sub-divided into 3 groups for separate testing. The final prepared copolymer concentrations were $0.4,0.8,1.2,1.6$, and $2.0 \mathrm{mg} \mathrm{ml}^{-1}$, respectively. The particle size and polydispersity of group 1 (Control) samples were determined by photon correlation spectroscopy (PCS) without further treatment. To assess the effect of a freeze-thaw (FT) process, group 2 samples were frozen at $-20{ }^{\circ} \mathrm{C}$ for $24 \mathrm{~h}$, and then allowed to thaw for $24 \mathrm{~h}$, before examination of particle size and polydispersity using PCS. To assess the effect of a freeze-dry (FD) and rehydration process, group 3 samples were frozen at $-20{ }^{\circ} \mathrm{C}$ for $24 \mathrm{~h}$, lyophilised for $18 \mathrm{~h}$ using a Christ Alpha 2-4 freeze dryer, and then rehydrated with 18.2 M $\Omega-c m$ deionised water (Elga Purelab ${ }^{\circledR}$ ) for $24 \mathrm{~h}$, before examination using PCS.

\section{Loading with the fluorescent probe Nile Red}

Solutions of the $\mathrm{MPC}_{100}-\mathrm{DPA}_{100}$ copolymer $\left(40 \mathrm{mg} \mathrm{ml}^{-1}\right.$ ) were prepared in $\mathrm{MeOH}$ with and without the hydrophobic fluorescent probe Nile Red (NR) (Sigma, UK) at $2 \mathrm{mg} \mathrm{ml}^{-1}$, based on a previously published polymer to NR weight loading ratio of 10:0.5 (Salvage et al. 2015). Aliquots $(100 \mu \mathrm{l})$ of these were added drop-wise, to $9.9 \mathrm{ml}$ of PBS, $\mathrm{pH} 7.4$, and the resultant samples $0.22 \mu \mathrm{m}$ pore size syringe filtered. The final prepared copolymer concentration was $0.4 \mathrm{mg} \mathrm{ml}^{-1}$.

\section{Coumarin-6 solubility in Methanol}

To determine the solubility of the fluorescent probe Coumarin-6 (Cm-6) (Sigma, UK) in $\mathrm{MeOH}$, a standard curve was constructed (Tan et al. 1976). Briefly, the lambda max $\left(\lambda_{\max }\right)$ absorbance of $\mathrm{Cm}-6$ in $\mathrm{MeOH}\left(20 \mu \mathrm{g} \mathrm{ml}^{-1}\right)$ was determined (457 nm) using a Lambda $25 \mathrm{UV} / \mathrm{Vis}$ spectrophotometer (PerkinElmer, UK), 200-700 nm scan, $1 \mathrm{~nm}$ spectral bandwidth. The absorbance of Cm-6 in $\mathrm{MeOH}$ solutions $\left(1,5,10,15 \mu \mathrm{g} \mathrm{ml}^{-1}\right)$ at $457 \mathrm{~nm}$ were recorded and a standard curve constructed. Finally, Cm- 6 in $\mathrm{MeOH}$ $\left(1 \mathrm{mg} \mathrm{ml}^{-1}\right)$ was prepared, $0.22 \mu \mathrm{m}$ pore size syringe filtered to remove undissolved $\mathrm{Cm}-6$, diluted 1 in 20 with $\mathrm{MeOH}$, the absorbance measured at $457 \mathrm{~nm}$, and $\mathrm{Cm}-6$ solubility in $\mathrm{MeOH}$ calculated from the standard curve.

\section{Loading with the fluorescent probe Coumarin-6}

Solutions of the $\mathrm{MPC}_{100}-\mathrm{DPA}_{100}$ copolymer $\left(40 \mathrm{mg} \mathrm{ml}^{-1}\right.$ ) were prepared in $\mathrm{MeOH}$ with and without the hydrophobic fluorescent probe Cm-6 at $0.3 \mathrm{mg} \mathrm{ml}^{-1}$, the Cm-6 solubility in $\mathrm{MeOH}$ was determined from the standard curve. Aliquots (100, 200, 300, 400, and $500 \mu \mathrm{l})$ of these solutions were added drop-wise to 9.9, 9.8, 9.7, 9.6, and $9.5 \mathrm{ml}$ of PBS (pH 7.4), respectively, the resultant samples $0.22 \mu \mathrm{m}$ pore size syringe filtered, and the absorbance measured at $457 \mathrm{~nm}$. The final prepared copolymer concentrations were $0.4,0.8,1.2,1.6$, and $2.0 \mathrm{mg} \mathrm{ml}^{-1}$, respectively. The Cm-6 loading capacity of the resultant $\mathrm{MPC}_{100}-\mathrm{DPA}_{100} \mathrm{PNM}$ systems was determined from the $\mathrm{Cm}-6$ in $\mathrm{MeOH}$ standard curve, corrected for blank PNM, and Cm-6 control absorbance.

\section{Particle size characterisation}

Particle size characterisation of the prepared $\mathrm{MPC}_{100^{-}}$ $\mathrm{DPA}_{100}$ PNM systems was undertaken using photon correlation spectroscopy (PCS), and cryo-scanning electron microscopy (Cryo-SEM).

\section{Photon correlation spectroscopy}

The PCS particle size measurements were undertaken using a Malvern Instruments Zetasizer Nano ZS90 equipped with a $633 \mathrm{~nm}$ HeNe laser and $90^{\circ}$ detector collection angle. PCS measurements were carried out in triplicate, at $25^{\circ} \mathrm{C}$, with a thermal equilibration time of $1 \mathrm{~min}$ per degree of temperature change, plus $5 \mathrm{~min}$, from room temperature, employed before PCS measurement commenced, the sample temperature was maintained by a 
Peltier thermal cuvette mounting stage. Each PCS size measurement had a duration of $120 \mathrm{~s}$, consisting of 12 subrun analyses (Pearson et al. 2013) by the Malvern PCS software, recording the fluctuations in the scattered light intensity, to determine the intensity based hydrodynamic diameter $\left(D_{\mathrm{h}}\right)$ and system polydispersity $(\mathrm{Pd})$. The $D_{\mathrm{h}}$ being calculated with the Stokes-Einstein equation $\left(D_{\mathrm{h}}=\mathrm{k} T / 3 \pi \eta d\right)$, where $D_{\mathrm{h}}=$ hydrodynamic diameter, $d=$ diffusion coefficient, $k=$ Boltzmann's constant, $T=$ absolute temperature, and $\eta=$ viscosity (Kaszuba et al. 2008). Samples were syringe filtered $(0.22 \mu \mathrm{m})$ prior to PCS measurement to ensure sample quality. Results determined, via the monomodal Cumulants analysis, to be polydisperse ( $\mathrm{Pd}>0.1)$ were further deconvolved using the Malvern software non-negative least squares (NNLS) based algorithm (Kaszuba et al. 2008), to resolve optimal particle size distributions (PSD) (Woodbury et al. 2006; Ansari and Nyeo 2012), with 50 and $200 \mathrm{~nm}$ monodisperse polystyrene nanoparticle standards (Duke Scientific, USA) employed to illustrate the principle of Cumulants versus NNLS analysis.

\section{Cryo-scanning electron microscopy}

The $\mathrm{MPC}_{100}-\mathrm{DPA}_{100}$ PNM system $\left(0.4 \mathrm{mg} \mathrm{ml}^{-1}\right)$ in PBS, pH 7.4, was examined under Cryo-SEM using a PP3000T cryogenic sample preparation system (Quorum Technologies, UK), together with a SIGMA field emission gun scanning electron microscope (FEG-SEM) (Zeiss, UK). The sample was flash frozen in slushy nitrogen, circa $-207^{\circ} \mathrm{C}$, on a Cryo-SEM sample holder, to avoid the Leidenfrost effect (Song et al. 2010), using the Quorum Prepdek $^{\mathrm{TM}}$ workstation. The frozen sample was transferred under vacuum to the Cryo-SEM exchange chamber, maintained at $-130^{\circ} \mathrm{C}$ with liquid nitrogen, and the sample freeze-fractured. The sample was sublimed at $-90^{\circ}$ $\mathrm{C}$ for $5 \mathrm{~min}$ to remove frozen water and reveal the PNM, a sputter coating of platinum $(5 \mathrm{~nm})$ applied, and the sample transferred to the Cryo-SEM stage within the FEG-SEM chamber. The Cryo-SEM stage and anti-contaminator were cooled to -130 and $-170{ }^{\circ} \mathrm{C}$, respectively, via capillary fed, liquid nitrogen cooled, nitrogen gas. The sample was FEG-SEM imaged at $2 \mathrm{kV}$ accelerating voltage, using a $30 \mu \mathrm{m}$ aperture, $8.5 \mathrm{~mm}$ working distance, and an Everhart-Thornley secondary electron detector.

\section{In vitro cellular cytotoxicity testing}

V79 fibroblast cell (ATCC, USA) and 3T3 fibroblast cell (ATCC, USA) stocks were maintained in Dulbecco's Modified Essential Medium (DMEM) (PAA, UK) supplemented with $10 \%$ foetal bovine serum (FBS) (PAA, UK) at $37{ }^{\circ} \mathrm{C}$ in $5 \% \mathrm{CO}_{2}$, with passage at $70-80 \%$ confluency.

\section{Cell colony formation assay}

The in vitro cell colony formation assay used a method fully described previously (Salvage et al. 2015), which had been successfully employed to test MPC-DPA systems. Briefly, $\mathrm{MPC}_{100}-\mathrm{DPA}_{100}$ PNM systems were prepared at $0.4 \mathrm{mg} \mathrm{ml}^{-1}$, with and without the hydrophobic fluorescent probes NR and $\mathrm{Cm}-6$ loaded. The $0.4 \mathrm{mg} \mathrm{ml}^{-1}$ MPC-DPA PNM systems were syringe filter sterilised $(0.22 \mu \mathrm{m})$ (Millipore, UK) before preparing a series of halving dilutions in DMEM (2.5 \% FBS) to provide polymer concentrations of $200,100,50,25,12.5$, and $6.25 \mu \mathrm{g} \mathrm{ml}^{-1}$. The samples were incubated, in triplicate, with V79 cells for 5 days at $37{ }^{\circ} \mathrm{C}$, in $5 \% \mathrm{CO}_{2}$, before fixing with $3.7 \%$ w/v formaldehyde (Sigma, UK) for $30 \mathrm{~min}$, and staining with $10 \% \mathrm{v} / \mathrm{v}$ Giemsa stain (Sigma, UK) for $30 \mathrm{~min}$. The colonies visible in each well were counted, and the cell survival percentage, for each dilution of each sample type, determined by comparison with control cells grown in cell medium only. Control samples of $\mathrm{MeOH}, \mathrm{MeOH}+\mathrm{Cm}-6$, $\mathrm{MeOH}+\mathrm{NR}$, and DMEM (2.5\% FBS) at the concentrations used for the polymer sample preparation were also tested. Triplicate repeats of the assay were performed for data robustness.

\section{MTT cell viability assay: Stage 1-comparability}

The in vitro 3-(4,5-dimethylthiazol-2-yl)-2,5-diphenyltetrazolium bromide (MTT) (Sigma, UK) cell viability assay was based on previously published methods (Mosmann 1983; Sieuwerts et al. 1995) and carried out in 2 stages of assessment. The first stage to establish the comparability of the MTT assay to the cell colony formation assay for testing MPC-DPA PNM systems using both V79 cells and 3T3 cells. The second stage to further evaluate the MTT assay using 3T3 cells for MPCDPA testing; primarily with regard to sample volume and concentration. For Stage 1 of the MTT assay using V79 cells, 24 well tissue culture (TC) plates (Nunc, UK) were seeded at a density of 10,000 cells per well (Benoit et al. 1997) in $1 \mathrm{ml}$ of DMEM (10\% FBS) and incubated at $37{ }^{\circ} \mathrm{C}$, in $5 \% \mathrm{CO}_{2}$ for $24 \mathrm{~h}$ to facilitate cell attachment. For Stage 1 of the MTT assay using 3T3 cells, 24 well TC plates were seeded at density of 15,000 cells per well (Lee et al. 2011) in $1 \mathrm{ml}$ of DMEM (10\% FBS) and incubated as per the V79 cells. $\mathrm{MPC}_{100^{-}}$ $\mathrm{DPA}_{100} \mathrm{PNM}$ systems were prepared at $0.4 \mathrm{mg} \mathrm{ml}^{-1}$, with and without $\mathrm{Cm}-6$ loaded. The $0.4 \mathrm{mg} \mathrm{ml}^{-1}$ MPCDPA PNM systems were filter sterilised $(0.22 \mu \mathrm{m})$ before preparing a series of halving dilutions in DMEM (10\% FBS) to provide polymer concentrations of 200, $100,50,25,12.5$, and $6.25 \mu \mathrm{g} \mathrm{ml}^{-1}$. The samples were incubated, in triplicate, with the TC plated V79 and 3T3 
cells for $24 \mathrm{~h}$ at $37{ }^{\circ} \mathrm{C}$, in $5 \% \mathrm{CO}_{2}$. Control samples of $\mathrm{MeOH}, \mathrm{MeOH}+\mathrm{Cm}-6$, and DMEM (10\% FBS) at the concentrations used for the polymer sample preparation were also tested. The cells were subsequently washed with PBS, and incubated with $1 \mathrm{ml}$ MTT in DMEM $\left(0.5 \mathrm{mg} \mathrm{ml}^{-1}\right)$ for $4 \mathrm{~h}$ at $37^{\circ} \mathrm{C}$ in $5 \% \mathrm{CO}_{2}$. The MTT medium was then removed, the cells washed with PBS, and $1 \mathrm{ml}$ dimethyl sulfoxide (DMSO) (Sigma, UK) added to each well to dissolve the formazan resulting from the interaction between the living test cells and MTT. $100 \mu \mathrm{l}$ of the DMSO formazan solution was transferred from each sample well to 96 well clear bottom assay plates (Nunc, UK) and the absorbance measured at $540 \mathrm{~nm}$ using a Labsystems Multiskan Ascent 354 microplate reader. The absorbance values of the test samples were compared to those of the control samples to calculate cell viability. Triplicate repeats of the assay were performed for data robustness.

\section{MTT cell viability assay: Stage 2-evaluation}

For Stage 2, evaluation of the MTT assay, 3T3 cells were seeded in 48 well TC plates (Nunc, UK) at a density of 7500 cells per well in $500 \mu \mathrm{l}$ of DMEM (10\% FBS) and incubated at $37{ }^{\circ} \mathrm{C}$, in $5 \% \mathrm{CO}_{2}$ for $24 \mathrm{~h}$. $\mathrm{MPC}_{100}-\mathrm{DPA}_{100}$ PNM systems, with and without Cm-6 loaded, were prepared at $2.0 \mathrm{mg} \mathrm{ml}^{-1}$. The $2.0 \mathrm{mg} \mathrm{ml}^{-1}$ MPC-DPA PNM systems were filter sterilised $(0.22 \mu \mathrm{m})$ before preparing a series of halving dilutions in DMEM (10\% FBS) to provide polymer concentrations of 1000, 500, 250, 125 and 62.5 , and $31.25 \mu \mathrm{g} \mathrm{ml}^{-1}$. Following the $24 \mathrm{~h}$ for cell attachment, the DMEM was replaced with $500 \mu \mathrm{l}$ of the test sample dilutions in triplicate, and the cells incubated for a further $24 \mathrm{~h}$ at $37{ }^{\circ} \mathrm{C}$, in $5 \% \mathrm{CO}_{2}$. Control samples of $\mathrm{MeOH}, \mathrm{MeOH}+\mathrm{Cm}-6$, and DMEM (10\% FBS) at the concentrations used for the polymer sample preparation were also tested. After $24 \mathrm{~h}$ incubation, the cells were washed with PBS, and incubated with $0.5 \mathrm{ml}$ MTT in $\operatorname{DMEM}\left(0.5 \mathrm{mg} \mathrm{ml}^{-1}\right)$ for $4 \mathrm{~h}$ at $37{ }^{\circ} \mathrm{C}$ in $5 \% \mathrm{CO}_{2}$. After MTT incubation, the wells were washed with PBS, before $200 \mu \mathrm{l}$ acidic ( $\mathrm{pH}$ 1.8) isopropanol (IPA) (Sigma, UK) was added to each well to dissolve the formazan. The IPA dissolved formazan $(100 \mu \mathrm{l})$ was transferred to 96 well assay plates and the absorbance measured at $540 \mathrm{~nm}$. The absorbance values of the test samples were compared to those of the control samples to calculate cell viability. Triplicate repeats of the assay were performed for data robustness.

\section{In vitro cellular uptake kinetics}

V79 and 3T3 cells were maintained as per the in vitro cellular cytotoxicity testing.
Intracellular uptake kinetics of Nile Red loaded MPC-DPA PNM

V79 cells were seeded into 12 well TC plates (Nunc, UK) at 5000 cells per well, in triplicate, in $1 \mathrm{ml}$ of DMEM (10\% FBS), and incubated at $37{ }^{\circ} \mathrm{C}$, in $5 \% \mathrm{CO}_{2}$ for $24 \mathrm{~h}$. $3 \mathrm{~T} 3$ cells were maintained, prepared, and incubated as per the V79 cells, in separate 12 well TC plates. $\mathrm{MPC}_{100^{-}}$ $\mathrm{DPA}_{100}$ PNM systems loaded with NR were prepared and diluted with DMEM (10\% FBS), to produce a final polymer concentration of $200 \mu \mathrm{g} \mathrm{ml}^{-1}$. The prepared PNM with NR system was filter sterilised $(0.22 \mu \mathrm{m})$, and used to replace the DMEM on the V79 and 3T3 cells. The test cells, with NR loaded PNM, were then incubated for a $24 \mathrm{~h}$ and $120 \mathrm{~h}$ at $37{ }^{\circ} \mathrm{C}$, in $5 \% \mathrm{CO}_{2}$. At each incubation time point (24 and $120 \mathrm{~h}$ ), a set of wells were washed twice with $1 \mathrm{ml}$ PBS, before applying fresh DMEM (10\% FBS) to each well. The cells were then observed for NR fluorescence (Greenspan et al. 1985) with a Leica SP5 confocal laser scanning microscopy (CLSM) (Leica, UK), using an excitation wavelength of $514 \mathrm{~nm}$, and an emission collection wavelength band of 524-674 nm

\section{Intracellular uptake kinetics of Coumarin-6 loaded MPC-DPA PNM}

3 T3 cells were seeded into 12 well TC plates at 5000 cells per well, in triplicate, in $1 \mathrm{ml}$ of DMEM (10\% FBS), and incubated at $37{ }^{\circ} \mathrm{C}$, in $5 \% \mathrm{CO}_{2}$ for $24 \mathrm{~h}$. $\mathrm{MPC}_{100}-\mathrm{DPA}_{100}$ PNM systems loaded with $\mathrm{Cm}-6$ were prepared and diluted with DMEM (10 \% FBS) to produce a final polymer concentration of $1 \mathrm{mg} \mathrm{ml}^{-1}$. The prepared PNM with Cm-6 system, was filter sterilised $(0.22 \mu \mathrm{m})$, and used to replace the DMEM on the $3 \mathrm{~T} 3$ cells. The cells were then incubated $\left(37{ }^{\circ} \mathrm{C}, 5 \% \mathrm{CO}_{2}\right)$ for a 1,4 , and $24 \mathrm{~h}$ to facilitate PNM uptake. At each time point $(1,4,24 \mathrm{~h})$, a set of cells were washed twice with $1 \mathrm{ml}$ PBS, fresh DMEM (10\% FBS) applied to each well, and the cells observed for Cm-6 fluorescence (Kristoffersen et al. 2014) with CLSM using an excitation wavelength of $488 \mathrm{~nm}$, and an emission collection wavelength band of 500-610 nm, to investigate the cellular uptake kinetics of the Cm-6 loaded $\mathrm{MPC}_{100^{-}}$ $\mathrm{DPA}_{100}$ PNM. Control samples of Cm-6 in DMEM (10\% FBS), at the concentrations used for the polymer sample preparation were also tested.

Intracellular fluorescence persistence of MPC-DPA PNM delivered $\mathrm{Cm}-6$

V79 cells were seeded into 12 well TC plates at 5000 cells per well, in triplicate, in $1 \mathrm{ml}$ of DMEM (10\% FBS), and incubated at $37{ }^{\circ} \mathrm{C}$, in $5 \% \mathrm{CO}_{2}$ for $24 \mathrm{~h}$. 3T3 cells were prepared as per the V79 cells, in separate 12 well TC 
plates. $\mathrm{MPC}_{100}-\mathrm{DPA}_{100} \mathrm{PNM}$ systems loaded with $\mathrm{Cm}-6$ were prepared and diluted with DMEM (10\% FBS) to produce a final polymer concentration of $200 \mu \mathrm{g} \mathrm{ml}^{-1}$. The prepared PNM with Cm-6 system, was filter sterilised $(0.22 \mu \mathrm{m})$, and used to replace the DMEM on the V79 and $3 \mathrm{~T} 3$ cells. The test cells, with Cm-6 loaded PNM, were then incubated for a further $24 \mathrm{~h}$ at $37^{\circ} \mathrm{C}$, in $5 \% \mathrm{CO}_{2}$. Following incubation, the wells were washed twice with $1 \mathrm{ml} \mathrm{PBS}$, and fresh DMEM (10\% FBS) applied to each well. The cells were then observed for Cm-6 fluorescence with CLSM, using an excitation wavelength of $488 \mathrm{~nm}$, and an emission collection wavelength band of $500-610 \mathrm{~nm}$, this was designated time point zero $(t=0)$. Following removal of the Cm-6 loaded PNM systems from the cells at the initial $(t=0)$ CLSM observation of Cm-6 fluorescence, incubation $\left(37^{\circ} \mathrm{C}, 5 \% \mathrm{CO}_{2}\right)$ of the V79 and $3 \mathrm{~T} 3$ cells, in DMEM (10\% FBS), was continued for a further $24 \mathrm{~h}(t=24)$, and $48 \mathrm{~h}(t=48)$. CLSM observation was undertaken at $t=24$ and $t=48$, to investigate persistence of PNM delivered intracellular Cm-6 fluorescence.

\section{Results and discussion}

\section{Synthesis and characterisation of $\mathrm{MPC}_{100}-\mathrm{DPA}_{100}$ block copolymer}

Synthesis of the $\mathrm{MPC}_{100}-\mathrm{DPA}_{100}$ diblock copolymer was undertaken via ATRP, and characterised with ${ }^{1} \mathrm{H}$ NMR and GPC. Figure 1a-d displays the ${ }^{1} \mathrm{H}$ NMR spectra, in $\mathrm{CDCl}_{3}: \mathrm{CD}_{3} \mathrm{OD}(3: 1 \mathrm{v} / \mathrm{v})$, the chemical structure, and NMR peak assignments, of the monomers MPC (a), and DPA (b), the ARTP initiator $\operatorname{MEBr}(\mathrm{c})$, and the resultant synthesised block copolymer MPC-DPA (d). The NMR peak assignments for MPC-DPA in Fig. 1d were consistent with previous reports of MPC-DPA synthesis (Pearson et al. 2013; Ruiz-Perez et al. 2015), indicating the ATRP synthesis was successful using the $\mathrm{MEBr}$ initiator, and $\mathrm{MeOH}$ solvent, at ambient room temperature. Regarding the choice of initiator, early studies reported successful utilisation of oligo(ethylene glycol) 2-bromoisobutyrate (OEGBr) for ATRP synthesis of homopolymers and block copolymers, such as PMPC (Lobb et al. 2001) and POEGMA (Wang and Armes 2000), including the first report of MPC-DPA copolymer synthesis (Ma et al. 2003). However, subsequent polymerisation studies utilising OEG and ME initiators (Robinson et al. 2002) indicated that OEG could form one of the copolymer blocks, directly affecting the resultant polymer properties, whilst in contrast, the ME group did not, and instead provided a convenient NMR label. Thus in later reports of MPC-DPA copolymer synthesis (Du et al. 2005) OEGBr, which could have acted as a third block in the copolymer, was replaced with MEBr due to its small size and lack of effect on the MPC-DPA properties, and hence the utilisation of $\mathrm{MEBr}$ in this current work. Whilst the synthesis reported herein was successful, it has been reported elsewhere that $\mathrm{MeOH}$ may produce transesterification of methacrylate monomers during ATRP (Bories-Azeau and Armes 2002; Connell et al. 2012), and as such future studies might consider using ethanol (EtOH) as an alternative solvent to $\mathrm{MeOH}$, although this may have an effect on the ATRP kinetics. As per the method of ATRP polymer synthesis utilised (Ma et al. 2003), and modified for this study, $\mathrm{MPC}_{100}$ polymerisation was monitored via ${ }^{1} \mathrm{H}$ NMR until circa $98 \%$ complete. The residual MPC monomer was preferentially consumed and polymerised after DPA monomer addition due to the higher reactivity of the MPC monomer, thus attaining a degree of polymerisation (DP) of 100 for MPC. The subsequent DP achieved for DPA, and the Mn(NMR) for the MPC-DPA copolymer, was confirmed with ${ }^{1} \mathrm{H}$ NMR by comparing the integrals of the methylene group protons in the MPC block at chemical shift $4.0 \mathrm{ppm}$, with the methine group protons in the DPA block at chemical shift $3.0 \mathrm{ppm}$, and methylene group protons in the DPA block at chemical shift $2.6 \mathrm{ppm}$, seen in Fig. 1d as peak assignments $f, l$, and $j$, respectively. This indicated a DP of 100 was attained for DPA, with the $\mathrm{Mn}(\mathrm{NMR})$ of 50,860 for the synthesised $\mathrm{MPC}_{100}-\mathrm{DPA}_{100}$ block copolymer being equal to the target $\mathrm{Mn}\left(\mathrm{g} \mathrm{mol}^{-1}\right)$.

The GPC elution profile data, for organic and aqueous GPC analysis of $\mathrm{MPC}_{100}-\mathrm{DPA}_{100}$ (Fig. 2) confirmed that appropriate choice of GPC system is critical for accurate GPC analysis of polymers to be achieved, as it can be seen that a single polymer can produce different elution profiles in different mobile phases. The molecular weight determinations and polydispersity are summarised in Table 1.

The aqueous GPC resulted in a broad elution profile (Fig. 2), similar to other reports of MPC polymer aqueous GPC analysis (Yamada et al. 2015), and aqueous $\mathrm{Mw}(\mathrm{GPC}), \mathrm{Mn}(\mathrm{GPC})$, and Mw/Mn (polydispersity) values of $63,170,38,950$, and 1.62 , respectively. In contrast, the organic GPC produced a sharp elution profile peak, and organic $\mathrm{Mw}(\mathrm{GPC}), \mathrm{Mn}(\mathrm{GPC})$, and $\mathrm{Mw} / \mathrm{Mn}$ (polydispersity) values of 58,150, 56,080, and 1.04, respectively. Additionally, the aqueous GPC used an RI detector, which are more susceptible to back pressure and temperature drift effects, and of lower sensitivity, than an ELS detector (Petritis et al. 2002), as employed herein for the organic GPC, and reflected by the reduced sample injection volumes and concentrations required. However, whilst the organic GPC appeared better suited for accurate analysis of the MPC-DPA polymer, than aqueous GPC, the organic $\mathrm{Mn}(\mathrm{GPC})$ value attained $(56,080)$ differed from the Mn(NMR) value $(50,860)$. This effect has been described in other polymer synthesis studies (Stenzel et al. 2004), 
(a)

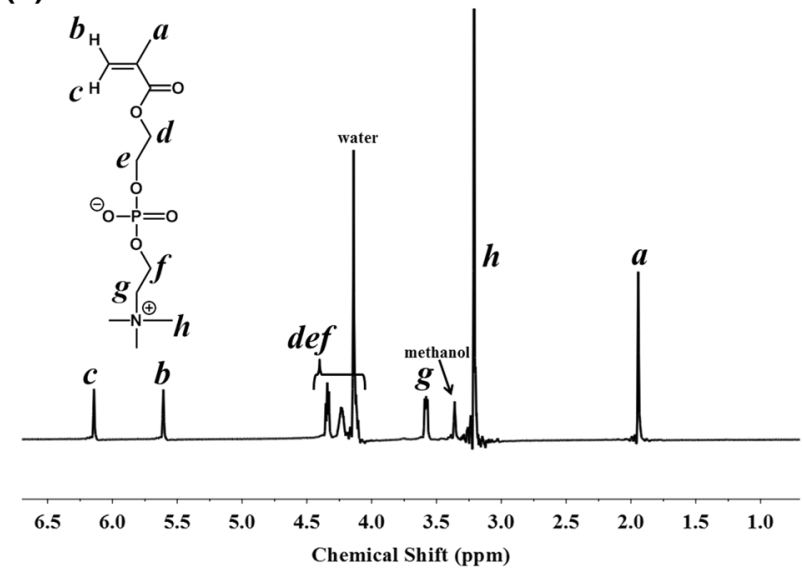

(c)

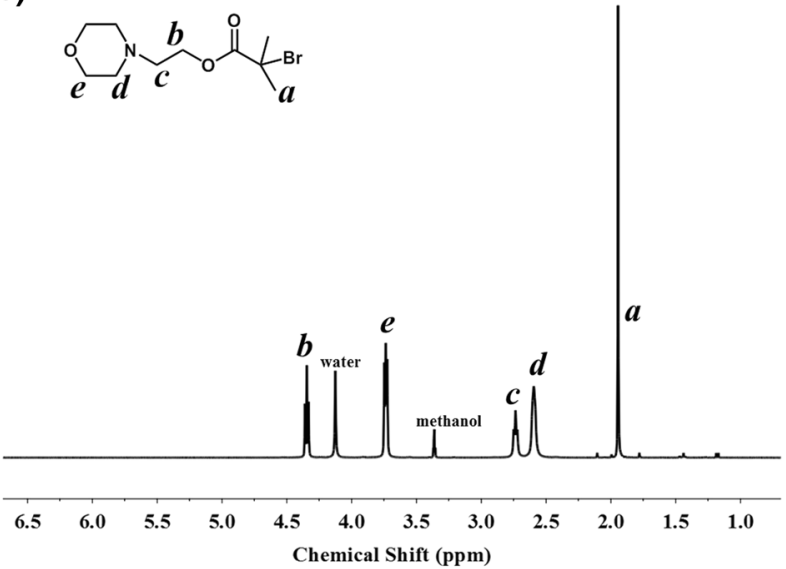

(b)

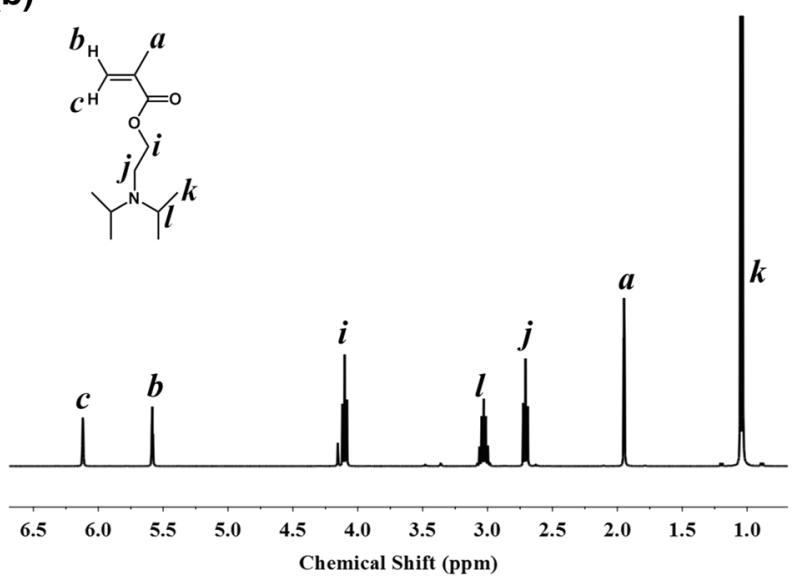

(d)

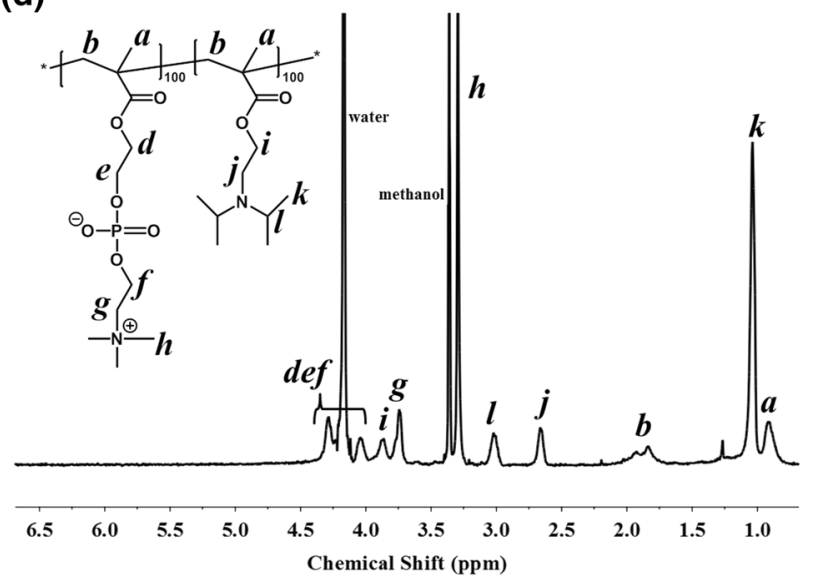

Fig. $1{ }^{1} \mathrm{H}$ NMR spectre, peak assignments, and chemical structure for a MPC, b DPA, $\mathbf{c} \mathrm{MEBr}$, and $\mathbf{d} \mathrm{MPC}_{100}-\mathrm{DPA}_{100}$, in $\mathrm{CDCl}_{3}: \mathrm{CD}_{3} \mathrm{OD}(3: 1$ $\mathrm{v} / \mathrm{v})$

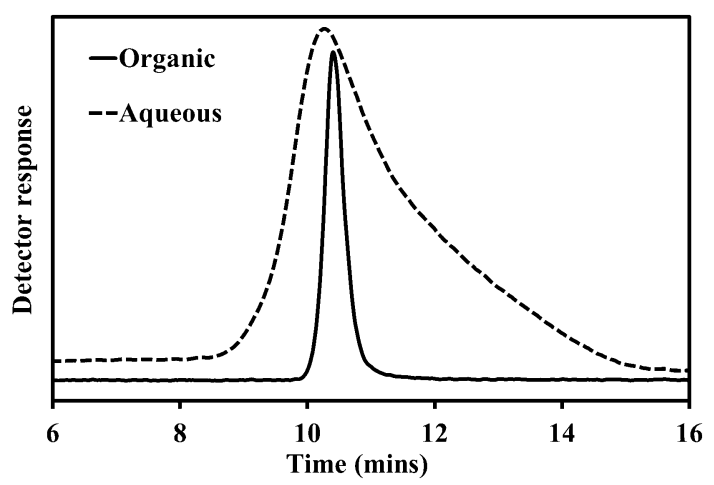

Fig. 2 GPC elution profiles for $\mathrm{MPC}_{100}-\mathrm{DPA}_{100}$ illustrating the effect of mobile phase type (organic vs. aqueous)

with NMR to GPC Mn differences of over $100 \%$ evident in some cases (Lin et al. 2014). Indeed, the aqueous GPC to NMR variance herein was circa $30 \%$, and other reports suggest that consistent MPC-DPA Mn(GPC) determination has also proven challenging previously (Du et al. 2005;
Lomas et al. 2010; Madsen et al. 2011, 2013; Yu et al. 2013), with apparent NMR to GPC differences of over $50 \%$ in some reports (Du et al. 2005; Madsen et al. 2013; $\mathrm{Yu}$ et al. 2013), but in this current study it was relatively low at circa $10 \%$ for the organic GPC analysis. The variance observed may be attributed to differences in the properties of the GPC standards compared to the test polymer, and the choice of mobile phase additives, particularly with MPC where intra- and inter-molecular electrostatic interactions are thought to produce hydrodynamic sizes that differ from those predicted (Mahon and Zhu 2008; Yamada et al. 2015), which is also applicable to GPC analysis of other polymer types (Lee and Chen 2010). Additionally, previous GPC analysis of MPC-DPA polymers has often utilised poly(methyl methacrylate) (PMMA) as the GPC calibration standards (Du et al. 2005; Lomas et al. 2010; Madsen et al. 2011, 2013). However, PMMA is hydrophobic and has low solubility in polar solvents such as $\mathrm{MeOH}$. Moreover, polymer characterisation studies have often added varying amounts of lithium bromide ( $\mathrm{LiBr}$ ) to 
Table 1 Molecular weight ( $\mathrm{Mn}$ and $\mathrm{Mw}$ ) and polydispersity (Mw/ $\mathrm{Mn})$ of block copolymer $\mathrm{MPC}_{100}-\mathrm{DPA}_{100}$ determined via ${ }^{1} \mathrm{H}$ NMR and GPC

\begin{tabular}{llll}
\hline $\mathrm{MPC}_{100}-\mathrm{DPA}_{100}$ & $\mathrm{Mn}$ & $\mathrm{Mw}$ & $\mathrm{Mw} / \mathrm{Mn}$ \\
\hline Target $\left(\mathrm{g} \mathrm{mol}^{-1}\right)$ & 50,860 & - & - \\
${ }^{1} \mathrm{H}$ NMR & 50,860 & - & - \\
GPC (Organic) & 56,080 & 58,150 & 1.04 \\
GPC (Aqueous) & 38,950 & 63,170 & 1.62 \\
\hline
\end{tabular}

the mobile phase (Stenzel et al.; 2004, Du et al. 2005; Lomas et al. 2010; Madsen et al. 2011, 2013; Penfold et al. 2015) to modify, shift, and sharpen the GPC elution profile (Coppola et al. 1972; Hann 1977; Dubin et al. 1977). Although this is an accepted GPC practice, it runs the risk of under or over compensation, with detector signal suppression being a potential consequence of the latter. For this study, non-volatile $\mathrm{LiBr}$ was not compatible with the ELS detector, and instead AcAc and TFA were added to the $\mathrm{CHCl}_{3}: \mathrm{MeOH}$ organic mobile phase to modify the $\mathrm{pH}$ for improved DPA compatibility. Additionally, PEG and PEO standards were employed, which, being amphiphilic, were soluble in both the organic and aqueous mobile phases, and thus more reflective of the hydrodynamic properties and hydrophilic nature of the MPC-DPA polymer, which may therefore account for the apparent improvement in GPC accuracy seen herein.

In summary, it is clear that appropriate and accurate GPC analysis of polymers presents unique challenges, and indeed, other studies have suggested GPC should only be seen as an Mw and Mn estimate (Yusa et al. 2005). Moreover, some reports have concluded that not all polymers are suitable for GPC analysis and instead have relied solely on NMR for Mn determination (Chu et al. 2009; Lee and Chen 2010) due to polymer hydrodynamic size, rather than molecular weight, influencing the GPC retention time (Yamada et al. 2015). However, in this current work the GPC analysis was effective, the data was comparable with NMR, and correlated well with the target molecular weight, the resultant organic GPC peak profile for $\mathrm{MPC}_{100}-\mathrm{DPA}_{100}$ (Fig. 2) was narrow and sharp, and the GPC(Mw/Mn) polydispersity (1.04) was low, indicating that the synthesised $\mathrm{MPC}_{100}-\mathrm{DPA}_{100}$ polymer was very well defined and of very good purity.

\section{Preparation of $\mathrm{MPC}_{100}-\mathrm{DPA}_{100}$ polymeric nanoparticle micelle systems}

\section{Polymer concentration, freeze-thaw, and freeze-dry rehydrate effect}

Nanoprecipitation offers the potential for the controlled and predictive assembly of biocompatible nanoparticles for

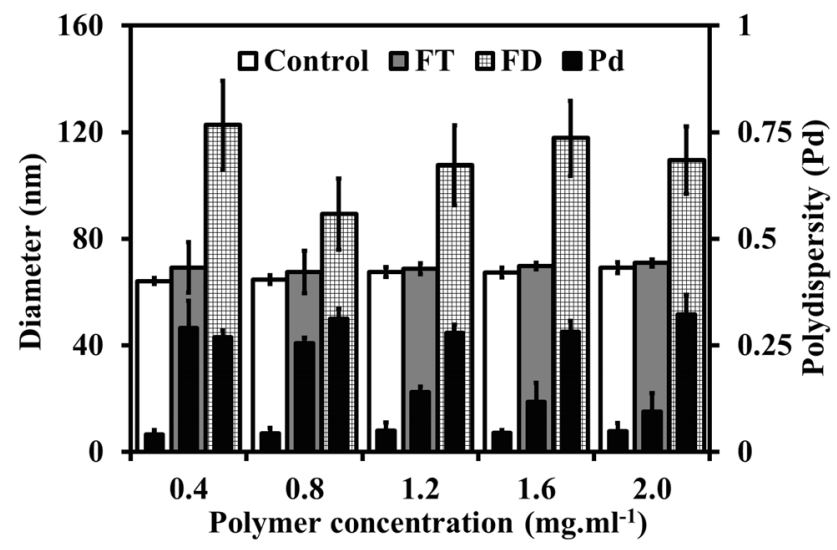

Fig. 3 Particle diameter (outer bar) and polydispersity (inner bar), measured with PCS, of $\mathrm{MPC}_{100}-\mathrm{DPA}_{100}$ micelles before (Control), and after, freeze-thaw (FT), and freeze-dry (FD) treatments (Mean $\pm \mathrm{SD}, n=3$ )

drug delivery based nanomedicine applications (Lepeltier et al. 2014), and the previous nanoprecipitation study of $\mathrm{MPC}_{100}-\mathrm{DPA}_{100}$ PNM demonstrated the potential for monodisperse nanoparticle formation (Salvage et al. 2015). Therefore, further studies investigating the effect of increasing polymer concentration, and the associated increase in $\mathrm{MeOH}$ volume, used during nanoprecipitation of MPC-DPA PNM were undertaken, together with the effects of post-nanoprecipitation FT and FD treatments. It can be seen from Fig. 3 that increasing polymer concentration, and associated $\mathrm{MeOH}$ volume relative to PBS, had an apparent effect on the overall $D_{\mathrm{h}}$ of the Control (CT) systems. The CT samples were analysed post-nanoprecipitation, and without further treatment, and displayed increasing $D_{\mathrm{h}}$ values ranging from circa $64 \mathrm{~nm}$ to $69 \mathrm{~nm}$ relative to increasing polymer concentration, which was in agreement with reports of nanoprecipitated particle sizes shifting with changes in polymer concentration and solvent volumes (Schubert and Muller-Goymann 2003; Bilati et al. 2005). However, whilst these earlier studies were indicative of possible particle size trends, it must also be taken into consideration that the nanoparticles formed are not directly comparable to the dynamic and fluid micelle systems self-assembled by MPC-DPA polymers, where micelle assembly is spontaneously driven by the hydrophobic effect and electrostatic forces (Tanford 1974; Kronberg et al. 1994), a multifaceted interaction that is not fully understood (Meyer et al. 2006). However, subsequent reports of nanoprecipitation being used to form micelles from block copolymers (Aliabadi et al. 2007) were consistent with the findings herein, and previously (Salvage et al. 2015), in that the solvent to non-solvent ratio, and the polymer concentration can affect the resultant micelle size, polydispersity, and loading capacity. Moreover, given that choice of solvent influences MPC-DPA PNM size (Salvage 
et al. 2015), and MPC-DPA polymers can form a range particle morphologies (Pearson et al. 2013), further study to help elucidate the effects seen would be useful. It can also be seen (Fig. 3) that the Pd values for the CT samples, remained stable and $<0.1$, thus indicating system monodispersity was maintained. The presence of $\mathrm{MeOH}$ in the systems is unlikely to have influenced the PCS, as previous work demonstrated that MPC-DPA PNM size, determined by PCS, remained stable and unchanged following dialysis and dilution to remove solvents (Salvage et al. 2015). The FT samples were subjected to a freezethaw process post-nanoprecipitation, and it can been seen from Fig. 3 that whilst this had little effect on the overall $D_{\mathrm{h}}$ of the samples, the Pd was affected, with all of the FT treated samples displaying an increased $\mathrm{Pd}$, which was greater for the lower $\left(0.4 \mathrm{mg} \mathrm{ml}^{-1}\right)$ polymer concentration samples compared to the higher $\left(2.0 \mathrm{mg} \mathrm{ml}^{-1}\right)$ concentration samples, relative to the untreated CT samples. The FD samples were subjected to a freeze-dry rehydration process, post-nanoprecipitation, and in contrast to the CT and FT samples, this produced distinct changes in the composition of the systems. As seen in Fig. 3, all of the FD samples displayed increased $D_{\mathrm{h}}$ and $\mathrm{Pd}$ values, relative to the untreated CT and FT treated samples, and irrespective of polymer concentrations tested, which was in agreement with reports that other polymer-based nanoparticle systems suffer stability issues upon freeze-drying (Cao and Jiang 2012; Logie et al. 2014).

When evaluating the results it is important to consider the different physical states each of the sample groups experienced. The CT samples were untreated, and thus remained in a liquid aqueous phase, and hence the $D_{\mathrm{h}}$ and $\mathrm{Pd}$ remained stable and monodisperse. The FT samples were frozen $\left(-20^{\circ} \mathrm{C}\right)$, and whilst this could help maintain system stability, ice formation upon freezing may have disrupted the uniformity and integrity of the micelles in suspension, and thus account for the increased Pd observed. Faster, snap freezing, to avoid ice crystal formation, may address the observed increase in $\mathrm{Pd}$ for the FT treated samples (Fig. 2), indeed the Cryo-SEM slushy nitrogen $\left(-207{ }^{\circ} \mathrm{C}\right)$ frozen sample appeared relatively monodisperse (Fig. 10). The FD samples were rehydrated from a lyophilised state, which may, to some degree, be considered similar to the manner in which MPC-DPA polymersomes are formed via film rehydration (Pegoraro et al. 2014), and thus resulted in systems with an increased $D_{\mathrm{h}}$ and $\mathrm{Pd}$, indicative of a polydisperse sample containing a mixed PSD (Woodbury et al. 2006; Ansari and Nyeo 2012).

The 50 and $200 \mathrm{~nm}$ polystyrene standard sample, shown in Fig. 4a illustrates how Cumulants analysis fits a Gaussian distribution to the PCS intensity data, and reports a single average intensity based diameter size $\left(D_{\mathrm{h}}\right)$ figure for the system, which whilst appropriate for monodisperse systems, does not truly reflect the population size distributions that may be contained within a polydisperse sample. For monodisperse samples, NNLS provides no additional information, but for polydisperse systems, NNLS can help to obtain optimal PSD information from the intensity based monomodal Cumulants data (Ansari and Nyeo 2012), and will thus provide a more realistic indication of sample consistency. This is clearly illustrated by the 50 and $200 \mathrm{~nm}$ standard peaks resolved with NNLS from a mixed polydisperse sample seen in Fig. 4a. Subsequent NNLS analysis of the FT samples (Fig. $4 \mathrm{~g}-\mathrm{k}$ ) revealed that the observed increase in $\mathrm{Pd}$ relative to decreasing polymer concentration (Fig. 3), was due to the presence of two particle populations, seen as two peaks (Fig. $4 \mathrm{~g}, \mathrm{~h}$ ) at the lower polymer concentrations $(0.4$ and $0.8 \mathrm{mg} \mathrm{ml}^{-1}$ ), with a transitional phase between polydisperse to monodisperse when the polymer concentration was $1.2 \mathrm{mg} \mathrm{ml}^{-1}$ (Fig. 4i). Similarly, when the polydisperse FD treated sample data was deconvolved with NNLS (Fig. 4l-p), it was clear that two discrete particle populations had also formed in the FD systems, the diameters of which were consistent with MPC-DPA mixed micelle and polymersome systems previously reported (Pearson et al. 2013). It should be noted, that when considering PCS sizing data, the size of the intensity distribution peaks should not be treated as an indication of the number contribution to overall sample composition, as the Rayleigh approximation indicates that the intensity of scattered light is proportional to particle diameter to the power of six $\left(\mathrm{D}^{6}\right)$ (Lucyanna et al. 2011), and thus the significance of larger particles is over represented.

In summary, the data (Figs. 3 and 4) suggest that the $\mathrm{MPC}_{100}-\mathrm{DPA}_{100}$ PNM systems prepared with increasing polymer concentrations were stable with regards to $D_{\mathrm{h}}$ and $\mathrm{Pd}$, and additionally, afforded a level of Cryo-protection and system stability, which was consistent with other reported studies of FT and FD polymeric nanoparticle systems (Date et al. 2010; Logie et al. 2014), and may be useful for improved storage and distribution of systems applied, for example, as stimuli ( $\mathrm{pH})$ responsive nanomedicines (Crucho 2015).

\section{Loading with the fluorescent probes Nile Red and Coumarin-6}

The $\mathrm{MPC}_{100}-\mathrm{DPA}_{100}$ PNM system was loaded with the hydrophobic dyes NR and Cm-6 via nanoprecipitation, and resulted in clearly visible increases (Fig. 5) in aqueous solubility for both NR (Fig. 5a, b), and Cm-6 (Fig. 5c, d). Loading micelles with hydrophobic compounds, such as NR and Cm-6, can result in particle size changes (Sharma et al. 2008), when the compounds preferentially partition 


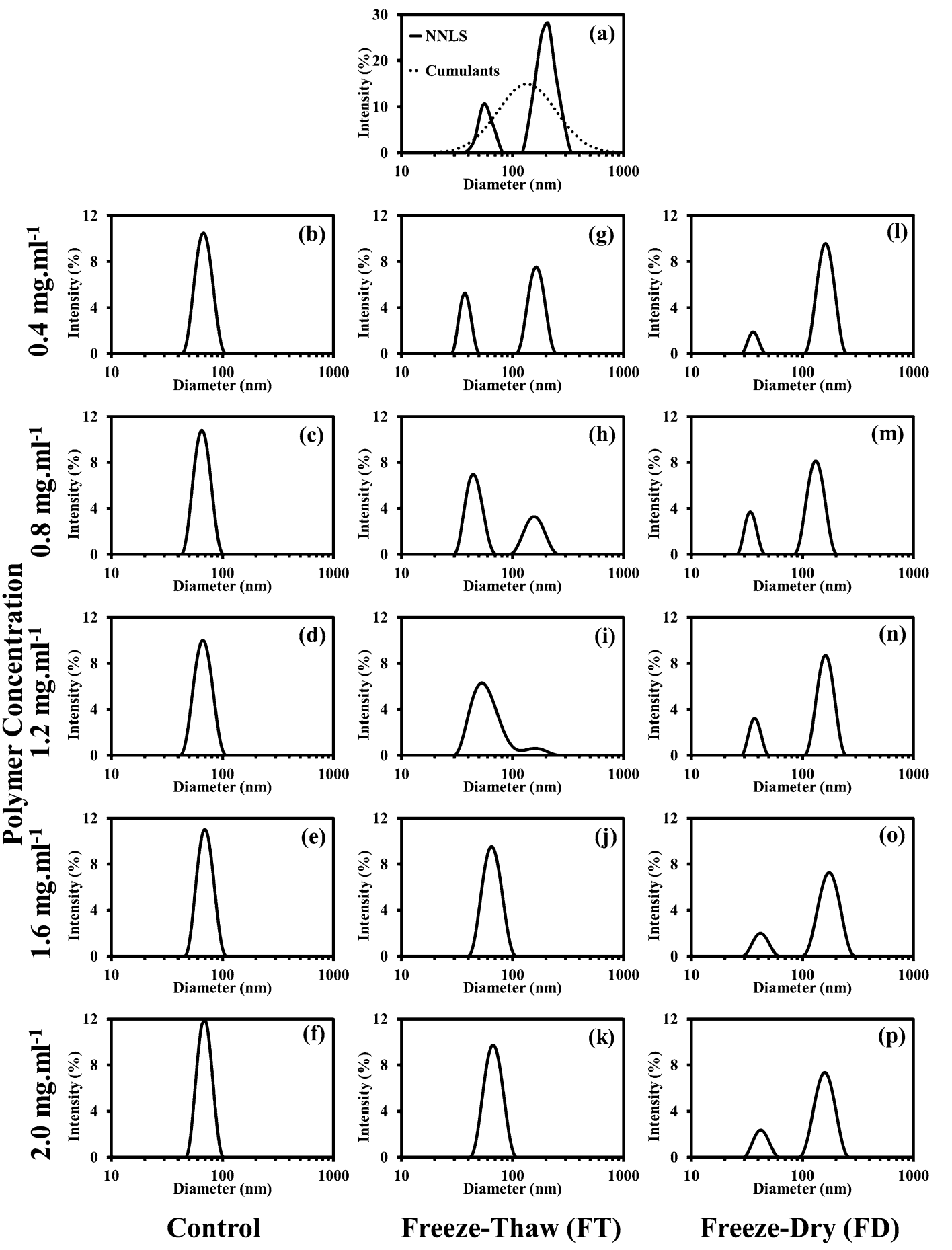

Fig. 4 PCS spectre $\left(25^{\circ} \mathrm{C}\right)$ of $\mathrm{MPC}_{100}-\mathrm{DPA}_{100} \mathrm{PNM}$ systems (PBS, pH 7.4) formed via nanoprecipitation, illustrating the effect of polymer concentration, freeze-thaw, and freeze-dry rehydrate treatments on particle population size and distribution

into the hydrophobic environment of the micelle cores (Marzio et al. 2008), and can also result in improved micelle stability (Kataoka et al. 2001). In this study loading with either NR or $\mathrm{Cm}-6$, at a polymer concentration of $0.4 \mathrm{mg} \mathrm{ml}^{-1}$, produced an apparent (circa 1-2 $\mathrm{nm}$ ) increase in the $D_{\mathrm{h}}$ of the PNM system (Fig. 6), with the Pd values remaining monodisperse, which was consistent with previous reports of both MPC-DPA (Licciardi et al. 2006) and other polymer based (Aliabadi et al. 2007; Sezgin et al. 2006) micelle size alterations upon hydrophobic loading. 


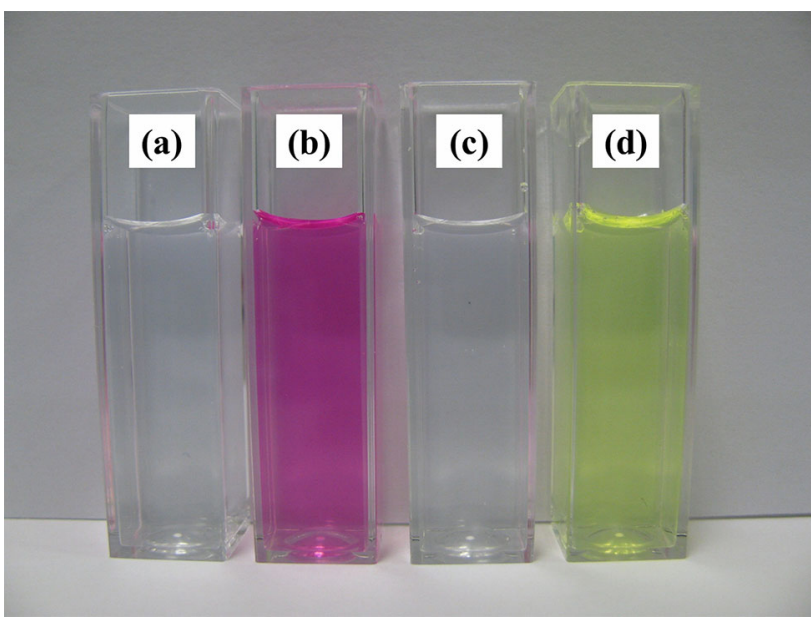

Fig. 5 Samples loaded with $\mathrm{NR}(\mathbf{a}, \mathbf{b})$ and $\mathrm{Cm}-6$ (c, d), via nanoprecipitation $(\mathrm{MeOH})$ into $\mathrm{PBS}(\mathrm{pH}$ 7.4), illustrating the improved solubility of $\mathrm{NR}$ (b) and $\mathrm{Cm}-6$ (d) in the presence of $\mathrm{MPC}_{100}-\mathrm{DPA}_{100}$ PNM

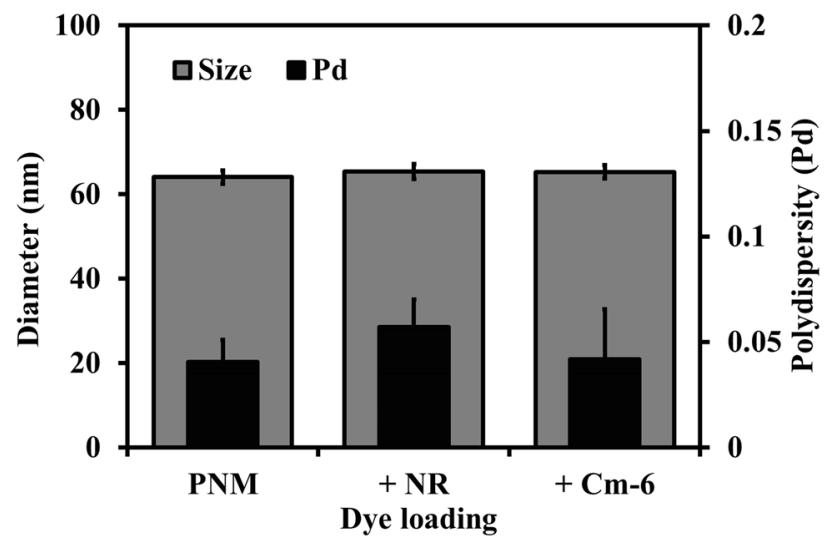

Fig. 6 Particle diameter (outer bar) and polydispersity (inner bar), measured with PCS $\left(25^{\circ} \mathrm{C}\right)$, of $\mathrm{MPC}_{100}-\mathrm{DPA}_{100}$ PNM systems (PBS, $\mathrm{pH}$ 7.4), formed via nanoprecipitation (MeOH-PBS), illustrating the effect of loading with NR and Cm- 6 on the $D_{\mathrm{h}}$ and Pd (Mean $\pm \mathrm{SD}$, $n=3$ )

\section{Coumarin-6 solubility in Methanol}

The solubility of $\mathrm{Cm}-6$ in $\mathrm{MeOH}$ was determined by constructing a standard curve (Tan et al. 1976) which is shown in Fig. 7. The $\lambda_{\max }$ measured for $\mathrm{Cm}-6$ in $\mathrm{MeOH}$ was $457 \mathrm{~nm}$, and was consistent with supplier (Acros, UK) specifications. The coefficient of determination $\left(R^{2}\right)$ value for the standard curve (Fig. 7) was 0.9995, suggesting the data possessed a good linear fit, and the $\mathrm{Cm}-6$ solubility in $\mathrm{MeOH}$ was calculated to be $0.3 \mathrm{mg} \mathrm{ml}^{-1}$, which was of the same order as $\mathrm{Cm}-6$ solubility in $\mathrm{CHCl}_{3}$ (Davda and Labhasetwar 2002), and significantly higher than the supplier (Sigma, UK) reported solubility in water of $0.25 \mu \mathrm{g} \mathrm{ml}^{-1}$.

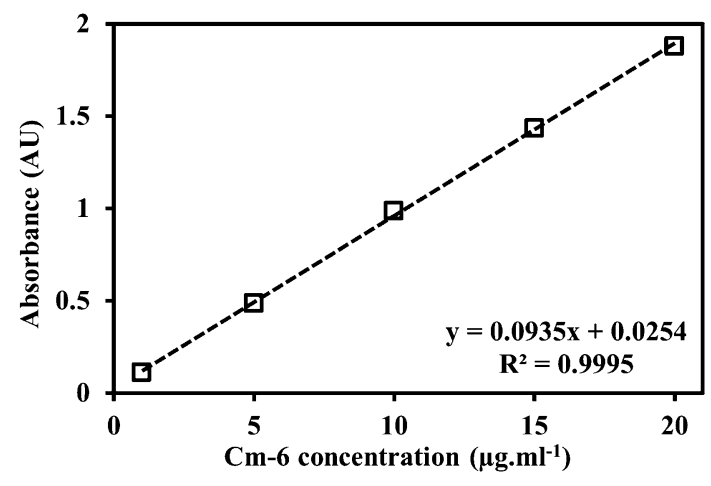

Fig. 7 Standard curve of Cm-6 solubility in $\mathrm{MeOH}$ at $457 \mathrm{~nm}$

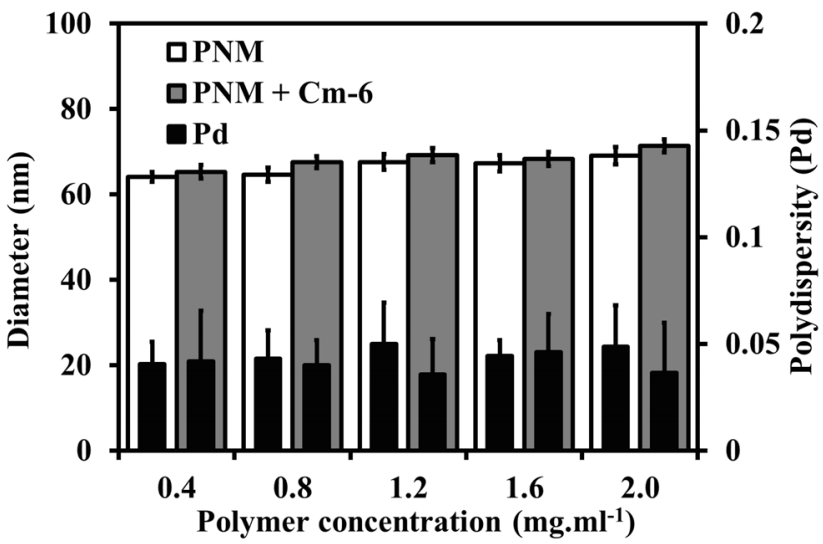

Fig. 8 Particle diameter (outer bar) and polydispersity (inner bar), measured with PCS $\left(25^{\circ} \mathrm{C}\right)$, of $\mathrm{MPC}_{100}-\mathrm{DPA}_{100} \mathrm{PNM}$ systems (PBS, $\mathrm{pH}$ 7.4), formed via nanoprecipitation (MeOH-PBS), illustrating the effect of increasing polymer concentration, and Cm-6 loading, on the $D_{\mathrm{h}}$ and $\mathrm{Pd}$ (Mean $\pm \mathrm{SD}, n=3$ )

\section{Loading with the fluorescent probe Coumarin-6}

Having determined the solubility of $\mathrm{Cm}-6$ in $\mathrm{MeOH}$ a series of $\mathrm{MPC}_{100}-\mathrm{DPA}_{100}$ PNM systems were prepared, via nanoprecipitation (MeOH-PBS), with and without $\mathrm{Cm}-6$ loaded, across a range of polymer concentrations (0.4-2.0 mg ml${ }^{-1}$ ) to determine the effect on $D_{\mathrm{h}}$ and Pd of the systems, and the loading efficiency of the systems. It can be seen from Fig. 8, that the effect noted and discussed previously in Fig. 6, whereby $D_{\mathrm{h}}$ increased by circa 1-2 nm upon Cm-6 loading, was also evident for the higher polymer concentration samples. Thus, $\mathrm{Cm}-6$ loading of the PNM produced $D_{\mathrm{h}}$ values ranging from circa 65 to $71 \mathrm{~nm}$ relative to increasing polymer concentration, whilst the $\mathrm{Pd}$ values again remained monodisperse, indicating good system stability.

The level of Cm-6 loading achieved with the $\mathrm{MPC}_{100^{-}}$ $\mathrm{DPA}_{100}$ PNM systems was determined from the standard curve (Fig. 7) and it can be seen from Fig. 9 that $\mathrm{Cm}-6$ 


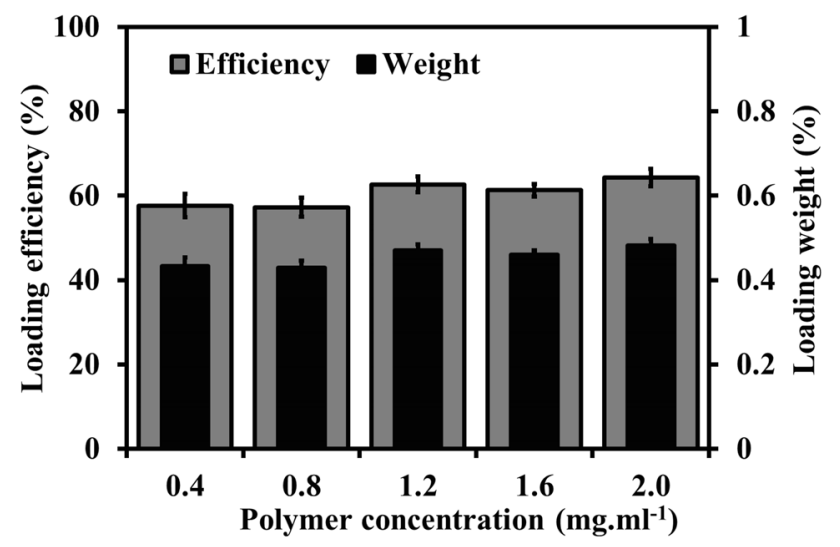

Fig. $9 \mathrm{Cm}-6$ loading efficiency (\%) (outer bar) and Cm-6 loading weight $(\%)$ (inner bar) achieved for $\mathrm{MPC}_{100}-\mathrm{DPA}_{100}$ PNM systems (PBS, $\mathrm{pH}$ 7.4), formed via nanoprecipitation (MeOH-PBS), illustrating the effect of increasing polymer concentration (Mean $\pm \mathrm{SD}$, $n=3$ )

loading efficiency (LE \%) ranged from circa 57-64\% relative to increasing polymer concentration, whilst the Cm-6 loading weight (LW \%) ranged from 0.43 to $0.48 \%$ (circa 4-5 $\mu \mathrm{g} \mathrm{Cm}-6$ per $\mathrm{mg}$ of polymer) relative to increasing polymer concentration, which should be viewed in context of the theoretical maximum weight loading of $0.75 \%$ ( $7.5 \mu \mathrm{g} \mathrm{Cm}-6$ per $\mathrm{mg}$ of polymer), due to the amount of Cm-6 utilised.

\section{LE $\%=[$ achieved loading $/$ theoretical loading $] \times 100$ \\ LW $\%=[$ achieved loading $/$ weight of PNM $] \times 100$}

Due to the principles of the nanoprecipitation method employed (Salvage et al. 2015), the weight loading was restricted by the solubility of $\mathrm{Cm}-6$ in $\mathrm{MeOH}$, and thus despite achieving circa $60 \%$ LE, which was comparable to previous reports of LE for MPC-DPA based polymersomes (Colley et al. 2014), the LW \% achieved (circa $0.5 \%$ ) was relatively low in contrast compared to other MPC-DPA micelle reports (Giacomelli et al. 2006; Licciardi et al. 2006, 2008). The LW \% (drug:polymer) achievable in this study was however restricted, and thus lower than previous reports, because the starting w/w \% ratio (drug:polymer) herein was 1:133, whilst comparable previous work (Giacomelli et al. 2006; Licciardi et al. 2006, 2008) had a w/w $\%$ preparation ratio of circa 1:10 (drug:polymer), and thus LW \% achieved was also tenfold higher at circa $5 \%$. Alternative MPC containing polymer micelles (Chu et al. 2009) have also reported higher LW \% being achieved, but again the preparation ratio of drug to polymer was higher at 1:5. However, on a pro-rata basis (circa 0.5 vs. $5 \%$ ) the $\mathrm{MPC}_{100}-\mathrm{DPA}_{100}$ PNM system tested herein performed comparably to other MPC-DPA systems. Also, given the desire to increase the efficacy of therapeutic compounds, whilst reducing the amount of drug required, this lower LW may be of advantage. It would be interesting to reduce the starting polymer concentration by tenfold, down to $40 \mu \mathrm{g} \mathrm{ml}^{-1}$, with $3 \mu \mathrm{g} \mathrm{ml}^{-1} \mathrm{Cm}-6$ (1:13 drug:polymer), to examine whether LE was maintained, and thus LW increased. However, that may also result in a reduced number of PNM in the system, which would act to attenuate attempts to increase LW \%. Additionally, it has been shown that the drug to polymer ratio can indeed have a marked effect on LE \% and LW \% achieved, together with influencing the resultant micelle size (Sezgin et al. 2006). This would be in agreement with previous reports of $\mathrm{MPC}_{100}-\mathrm{DPA}_{100}$ PNM (Salvage et al. 2015), where micelle size was increased by over $100 \%$ at a high polymer to drug ratio. Despite the apparently low LW \% achieved, compared to other MPC-DPA reports, when the current data is compared to reports of alternative nanoparticle systems loaded with Cm-6 (Trapani et al. 2009) and micelles loaded with cyclosporine A (Aliabadi et al. 2007), the results of this study compare favourably and indeed exceed the previous LW and LE levels reported. It may also be interesting to investigate nanoprecipitation using alternative solvents to determine whether LE and LW can be increased, however it is noted that previous reports of solvent effects on MPC polymers (Lewis et al. 2000; Edmondson et al. 2010; Salvage et al. 2015) indicate that this may also alter the size and morphology of the resultant nanoparticles.

In summary, the $\mathrm{MPC}_{100}-\mathrm{DPA}_{100}$ PNM systems have been successfully loaded with hydrophobic model compounds in the form of the fluorophores NR (Fig. 6) and Cm-6 (Fig. 8), with the $D_{\mathrm{h}}$ and Pd of the PNM systems remaining stable, and good loading efficiency achieved (Fig. 9), indicating further their potential application as polymeric nanomedicine vectors (Khemtong et al. 2009).

\section{Particle size characterisation}

Particle size characterisation of the $\mathrm{MPC}_{100}-\mathrm{DPA}_{100}$ micelles was undertaken using PCS, and Cryo-SEM. The data from the PCS analysis of the PNM systems (Figs. 6 and 8) indicated that the PSD were monodisperse $(\mathrm{Pd}<0.1)$ and displayed $D_{\mathrm{h}}$ values of circa 64-69 nm (PNM) and 65-71 nm (PNM + NR/Cm-6). The Cryo-SEM image data (Fig. 10) was in agreement with the PCS data (Fig. 6), displaying a uniform PSD and morphology, with PNM diameters of circa $65 \mathrm{~nm}$. The observed morphology (Fig. 10) of these MPC-DPA PNM was consistent with the physical shape and appearance of other Cryo-SEM imaged micelle systems (Issman and Talmon 2012; Basak and Bandyopadhyay 2013). A PCS investigation of the effects of freezing, and freeze drying, upon the PNM systems revealed a marked effect on the PSD of the $\mathrm{MPC}_{100^{-}}$ $\mathrm{DPA}_{100}$ system, as seen in Fig. 4, which was relative to polymer concentration and treatment, as discussed earlier. 


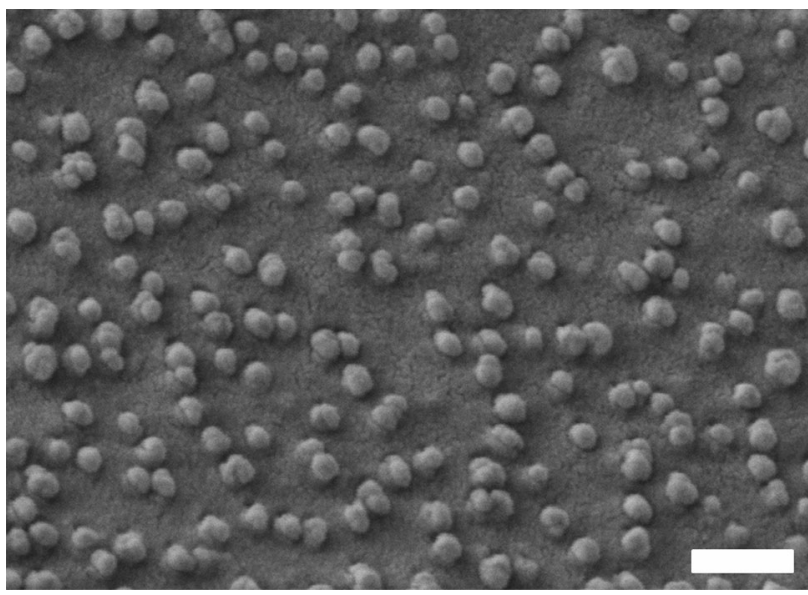

Fig. 10 Cryo-SEM image of $\mathrm{MPC}_{100}-\mathrm{DPA}_{100}$ polymeric nanoparticle micelles displaying diameters of circa 65-70 nm. Scale bar $=200 \mathrm{~nm}$

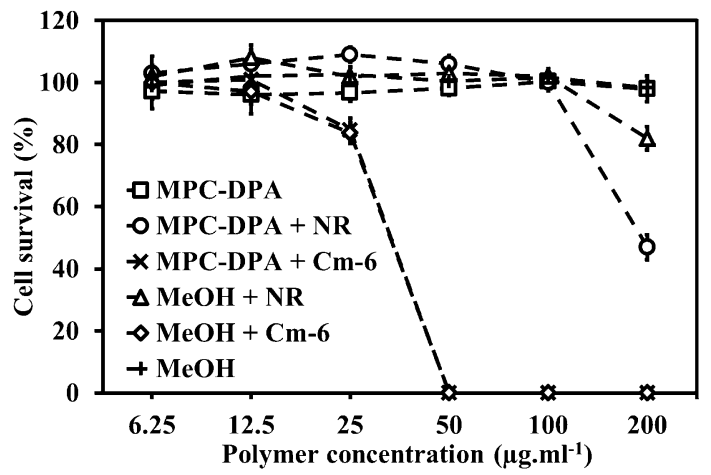

Fig. 11 V79 cell colony formation in vitro cytotoxicity assay of the $\mathrm{MPC}_{100}-\mathrm{DPA}_{100}$ PNM systems (PBS, pH 7.4) with and without NR and $\mathrm{Cm}-6$ loaded. Percent survival derived from comparison to cell medium control wells. Samples incubated for 5 days at $37{ }^{\circ} \mathrm{C}$ in $5 \%$ $\mathrm{CO}_{2}($ Mean $\pm \mathrm{SD}, \mathrm{n}=3)$

\section{In vitro cellular cytotoxicity testing}

\section{Cell colony formation assay}

Cell colony formation assays are a well-established technique for determining cell survival (Franken et al. 2006), a variant utilising V79 cells has previously been used to test MPC-DPA PNM (Salvage et al. 2005, 2015), and in this study was employed further for the investigation of MPC $_{100}-\mathrm{DPA}_{100}$ PNM systems with the addition of loaded hydrophobic compounds (NR and $\mathrm{Cm}-6$ ). The data seen in Fig. 11 was consistent with previous MPC-DPA data, in that the PNM alone were essentially non-toxic at the concentrations tested $\left(6.25-200 \mu \mathrm{g} \mathrm{ml}^{-1}\right)$. However, it was found that the NR loaded MPC-DPA PNM samples, and $\mathrm{MeOH}-\mathrm{NR}$ samples, displayed reduced cell survival rates of circa 50 and $80 \%$, respectively, at $200 \mu \mathrm{g} \mathrm{ml}^{-1}$. The data
(Fig. 11) would suggest that the reduced cell survival was due to the NR, as the MPC-DPA, and MeOH controls did not produce a reduction. The use of $\mathrm{MeOH}$ in nanoprecipitation, and the associated risks of $\mathrm{MeOH}$ toxicity, have been discussed in depth previously (Salvage et al. 2015). Additionally, the data at $200 \mu \mathrm{g} \mathrm{ml}^{-1}$ also suggested that loading NR into MPC-DPA PNM, increased the apparent NR toxicity, possibly due to the more effective intracellular delivery of the NR by the PNM, the occurrence of which is supported by Fig. 15. Such an affect would be consistent with previous reports of enhanced delivery utilising MPCDPA polymersome based nanoparticle systems (Pegoraro et al. 2013). In contrast, the samples containing Cm-6 displayed a much greater level of cell toxicity, with an apparent reduction to circa $80 \%$ survival at $25 \mu \mathrm{g} \mathrm{ml}^{-1}$, and $0 \%$ survival from $50-200 \mu \mathrm{g} \mathrm{ml}^{-1}$ concentration, with cellular uptake of Cm-6 supported by Fig. 17. Previous work on MPC-DPA PNM dilution stability (Salvage et al. 2015), suggests that the PNM were above their critical micelle concentration (CMC) at the levels employed and tested for this study. There have been other reports of NR (Lin et al. 2009; Snipstad et al. 2014; Drozdek and Bazylinska 2015) and Cm-6 (Davda and Labhasetwar 2002; Sun et al. 2010; Rivolta et al. 2011; Tang et al. 2011; Zhang et al. 2014; Drozdek and Bazylinska 2015) nanoparticle mediated intracellular delivery, often without toxicity issues, however the extended period of the Cm- 6 exposure involved in the V79 colony formation assay of 5 days $(120 \mathrm{~h})$, may have served to augment the apparent NR and Cm-6 toxicity seen herein. The V79 colony formation assay, whilst useful as an initial gauge of potential cytotoxicity is limited by its design, in that the low seeding density employed is suboptimal for many cell lines, and can result in cell death or impaired cell growth (Rubin et al. 1995), hence an MTT assay is often employed instead (Nikzad and Hashemi 2014).

\section{MTT cell viability assay: Stage 1-comparability}

It has been suggested that Coumarin compounds have the potential for therapeutic applications (Kontogiorgis et al. 2012), and thus further work for this study focused on the Cm-6 systems, with the MTT assay (Mosmann 1983; Sieuwerts et al. 1995) employed to facilitate comparative testing between V79 cells and 3T3 cells, both of which are well established and widely used in vitro research cell lines. The V79 MTT assay data (Fig. 12) was reflective of, and consist with, the V79 colony assay data (Fig. 11) where the MPC-DPA PNM, and $\mathrm{MeOH}$, controls, were essentially non-toxic, whilst the $\mathrm{Cm}-6$ loaded MPC-DPA PNM and $\mathrm{MeOH}-\mathrm{Cm}-6$ samples produced an apparent reduction in cell viability at polymer test concentrations of 50-200 $\mu \mathrm{g} \mathrm{ml}^{-1}$. The Cm-6 associated reduction in V79 


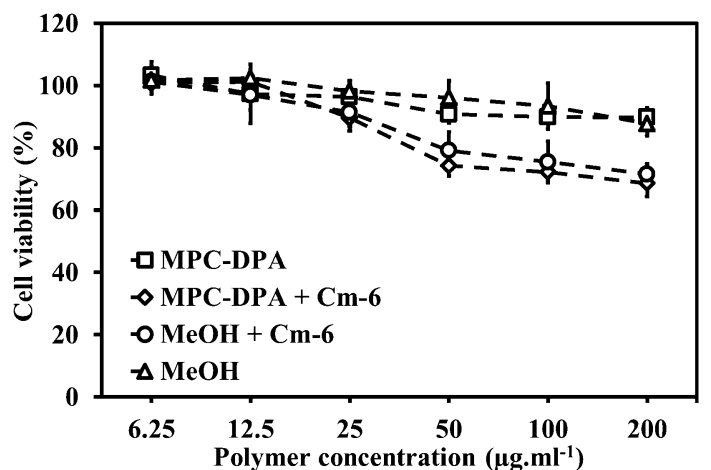

Fig. 12 V79 cell MTT in vitro cytotoxicity assay of the $\mathrm{MPC}_{100^{-}}$ DPA $_{100}$ PNM systems (PBS, pH 7.4) with and without $\mathrm{Cm}-6$ loaded. Percent viability derived from comparison to cell medium control wells. Samples incubated for $24 \mathrm{~h}$ at $37{ }^{\circ} \mathrm{C}$ in $5 \% \mathrm{CO}_{2}$ (Mean $\pm \mathrm{SD}$, $n=3$ )

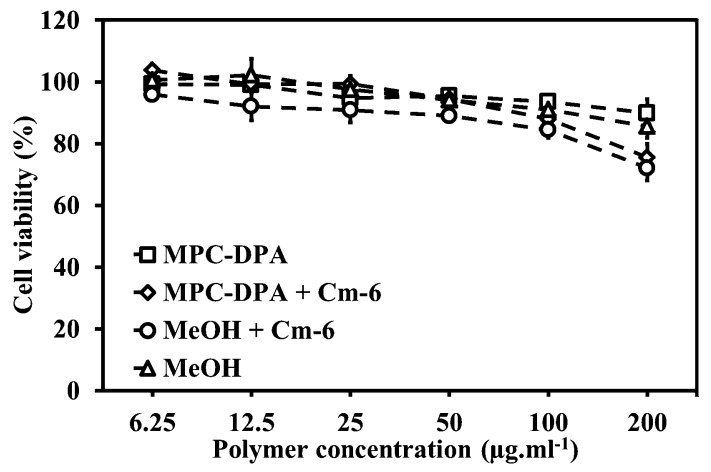

Fig. 133 T3 cell MTT in vitro cytotoxicity assay of the $\mathrm{MPC}_{100^{-}}$ DPA $_{100}$ PNM systems (PBS, pH 7.4) with and without Cm-6 loaded. Percent viability derived from comparison to cell medium control wells. Samples incubated for $24 \mathrm{~h}$ at $37{ }^{\circ} \mathrm{C}$ in $5 \% \mathrm{CO}_{2}$ (Mean $\pm \mathrm{SD}$, $n=3$ )

cell viability to circa $70-80 \%$ seen in Fig. 12, was less marked than the reduction to $0 \% \mathrm{~V} 79$ cell survival seen in Fig. 11. However, the MTT assay involved a much shorter sample incubation time of $24 \mathrm{~h}$, compared to $120 \mathrm{~h}$ for the colony assay, which may have attenuated the apparent $\mathrm{Cm}$ 6 cellular toxicity towards the V79 cells seen in Fig. 11. In contrast to the V79 MTT data (Fig. 12), when the samples were tested with 3T3 cells using the MTT assay (Fig. 13) the apparent toxicity of Cm-6 was much less evident. The control samples of MPC-DPA PNM, and $\mathrm{MeOH}$, were again essentially non-toxic, and consistent with the results seen in Figs. 11 and 12, whilst the only discernible reduction in cell viability for the $\mathrm{Cm}-6$ containing samples, to circa $70 \%$, was at the highest polymer concentration level $\left(200 \mu \mathrm{g} \mathrm{ml}^{-1}\right)$ tested. This apparent difference between V79 and 3T3 cell sensitivity to $\mathrm{Cm}-6$, is consistent with other reports of in vitro response variability between V79 and 3T3 cells (Sivak et al. 1982) and in this instance may be due to the reported differences in kinase $\mathrm{C}$ levels

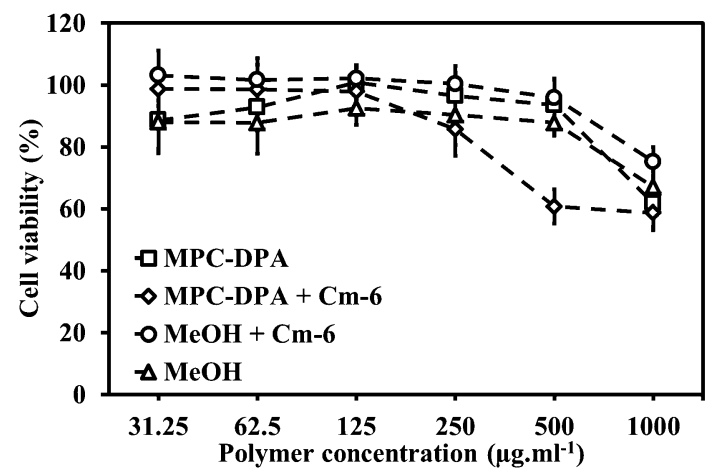

Fig. $143 \mathrm{~T} 3$ cell MTT in vitro cytotoxicity assay of the $\mathrm{MPC}_{100^{-}}$ DPA $_{100}$ PNM systems (PBS, pH 7.4) with and without Cm-6 loaded. Percent viability derived from comparison to cell medium control wells. Samples incubated for $24 \mathrm{~h}$ at $37{ }^{\circ} \mathrm{C}$ in $5 \% \mathrm{CO}_{2}$ (Mean $\pm \mathrm{SD}$, $n=3$ )

between V79 and 3T3 cells (Adams and Gullick 1989), as kinase $\mathrm{C}$ has been linked to endocytosis regulation (Le et al. 2002), and thus PNM uptake levels. Additionally, it has also been reported that the toxicity of Coumarin compounds varies between species (Lake and Grasso 1996) sometimes profoundly (Born et al. 2000), and given that V79 cells are of hamster origin, whilst 3 T3 cells are of mouse, this may also have influenced the results herein. However, when Figs. 11, 12, and 13 are compared it is reasonable to conclude that the MTT assay was comparable to the colony formation assay for effective detection and quantification of cellular toxicity, and the data was consistent with the CLSM data for the Cm- 6 exposed cells seen in Figs. 16 and 17.

\section{MTT cell viability assay: Stage 2-evaluation}

Given the apparent sensitivity of V79 cells to Cm-6 (Figs. 11 and 12), further Stage 2 MTT assay evaluation focused on $3 \mathrm{~T} 3$ cells to facilitate testing of the PNM systems at higher preparation concentrations, smaller sample volumes, and with an alternative solvent for the formazan. The reduced scale being desirable for efficiency, and both DMSO and IPA have been reported as MTT assay solvents (Mosmann 1983; Sieuwerts et al. 1995). The results of the Stage 2 MTT testing of the MPC-DPA PNM systems, with and without $\mathrm{Cm}-6$ loaded, can be seen in Fig. 14. The data were consistent with the lower concentration, larger volumes tested (Fig. 13), in that polymer concentrations below $250 \mu \mathrm{g} \mathrm{ml}^{-1}$ were essentially non-toxic. However there was an apparent increase in the toxicity, with cell viability reduced to circa $60 \%$, for the MPC-DPA PNM, with $\mathrm{Cm}-6$ loaded, at the higher polymer concentration of $500 \mu \mathrm{g} \mathrm{ml}^{-1}$, shown in Fig. 14. This was similar to the effect seen in Figs. 11 and 12, and as discussed previously may be due to enhanced intracellular delivery of the Cm-6 
Fig. 15 Confocal laser scanning microscopy images of V79 and 3T3 cells incubated with $\mathrm{MPC}_{100}-\mathrm{DPA}_{100} \mathrm{PNM}$ systems (PBS, pH 7.4), loaded with NR, for 24 and $120 \mathrm{~h}$, displaying intracellular fluorescence indicative of PNM uptake. Scale bar $=25 \mu \mathrm{m}$
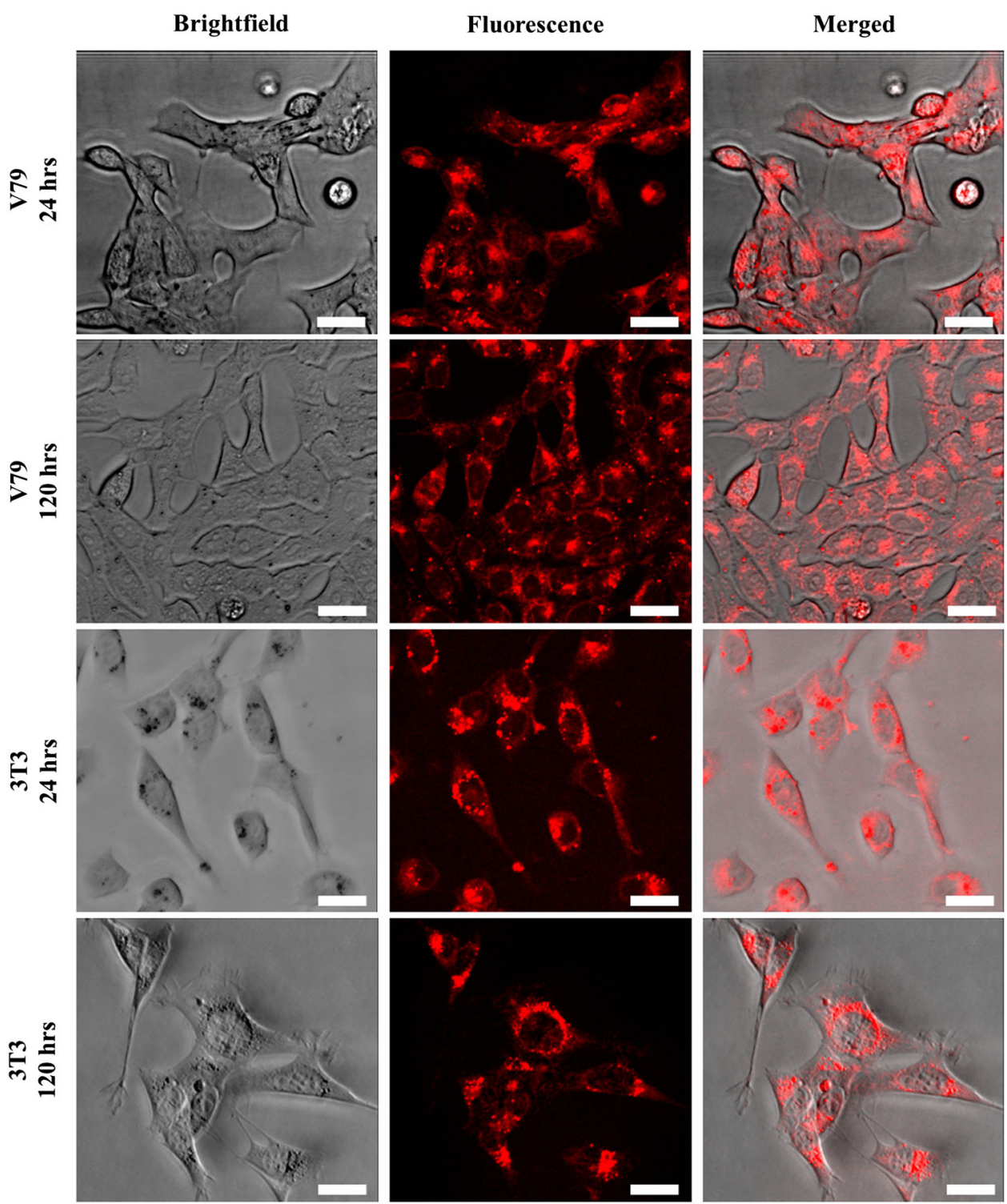

by the MPC-DPA PNM system. At the highest concentration tested, $1 \mathrm{mg} \mathrm{ml}^{-1}$, all samples produced a reduction in 3T3 cell viability, ranging from circa 60-70\%, but remained above $\mathrm{IC}_{50}$ levels (Sieuwerts et al. 1995), this was possibly the result of initial DMEM dilution with the test samples (Salvage et al. 2015), as other MPC-DPA based polymers have demonstrated low cellular toxicity at up to $5 \mathrm{mg} \mathrm{ml}^{-1}$ in polymersome form (Lomas et al. 2008). Overall the data in Fig. 14 was consistent with Fig. 13, indicating the use of smaller test volumes, and acidified IPA in place of DMSO, was acceptable and effective. With regard to the direct comparison of the two assay types, MTT determines cell viability by testing inhibition of cell growth and inducement of cell death, whilst the colony assay determines cell survival based on the ability of a cell to grow into a colony. Additionally, it is also important to consider that the colony formation assay is more prone to user variability due to the subjective nature of visually counting colonies compared with the colorimetric MTT assay, and hence it is not unusual to find papers employing both techniques to characterise novel materials (Gao et al. 2012), indeed there are papers dedicated to exploring the comparisons (Nikzad and Hashemi 2014, Fotakis and Timbrell 2006), however in this current study the colony formation assay and the MTT assay data were in general agreement.

\section{In vitro cellular uptake kinetics}

Intracellular uptake kinetics of Nile Red loaded MPC-DPA PNM

Upon PNM delivery of NR to V79 and 3T3 cells, there was visible NR fluorescence evident with CLSM in both the 
cells types after $24 \mathrm{~h}$ exposure, as seen in Fig. 15, with concentrated areas of NR florescence within the cellular cytoplasm, indicative of successful PNM uptake and NR delivery. This was consistent with, and an improvement upon, the previous findings of intracellular uptake after $48 \mathrm{~h}$ (Salvage et al. 2015). Due to the hydrophobic and lipophilic nature of NR, it is probable that the NR may have undergone intracellular lipid interactions (Diaz et al. 2008), with the NR fluorescence primarily contained within the cell cytoplasm, and generally absent from the nucleus, which the merged images in Fig. 15 appear to support, and is consistent with other reports of intracellular dye localisation (Drozdek and Bazylinska 2015, Stefancíkova et al. 2014). The V79 and 3T3 cells were viable and NR fluorescently stained after both the 24 and $120 \mathrm{~h}$ exposure periods, with the $120 \mathrm{~h}$ exposure being representative of the 5 days colony assay incubations period, and consistent with the cell survival data seen in Fig. 11, although it was noted that the 3T3 cells appeared to be more active, with pseudopodia visible, in a similar manner to $\mathrm{Cm}-6$ exposed 3T3 cells seen in Fig. 17.

\section{Intracellular uptake kinetics of Cm-6 loaded MPC-DPA PNM}

Cm-6 uptake by $3 \mathrm{~T} 3$ cells was confirmed by the intracellular fluorescence observed using CLSM, as shown in Fig. 16. The control $\mathrm{Cm}-6$ samples displayed very little fluorescence at $1 \mathrm{~h}$, with that being detectable located primarily outside of the cells either in the surrounding aqueous medium, or on the cell surface due to the hydrophobic nature of $\mathrm{Cm}-6$. After $4 \mathrm{~h}$ incubation the extracellular control Cm-6 accumulation and fluorescence appeared to have increased, but there was no evidence of intracellular uptake, which was consistent with similar reports (Zhang et al. 2014), and after $24 \mathrm{~h}$ it became apparent that the control $\mathrm{Cm}-6$ was adsorbed to the outer cell surface (Fig. 16) and not internalised, with only minimal $\mathrm{Cm}-6$ fluorescence visible, and consistent with other free $\mathrm{Cm}-6$ cell exposure studies (Drozdek and Bazylinska 2015). In contrast the 3 T3 cells exposed to MPC-DPA PNM delivered $\mathrm{Cm}-6$ displayed clear intracellular Cm-6 fluorescence after $1 \mathrm{~h}$ exposure, and increasing at 4 and $24 \mathrm{~h}$. This enhanced and rapid $1 \mathrm{~h}$ intracellular delivery of MPC-DPA micelles was consistent with previous reports for both MPC-DPA polymersome (Lomas et al. 2008), and other polymeric micelle system (Zhang et al. 2014; Tu et al. 2011) cellular uptake. It is thought that class B cell surface scavenger receptor medicated endocytosis is responsible for PC-based nanoparticle uptake (Boullier et al. 2005; Colley et al. 2014). Interestingly, it has also been suggested that very rapid uptake, occurring within minutes of exposure, may be the result of cell contact mediated diffusion rather than endocytosis (Snipstad et al. 2014). Examination of the CLSM images (Fig. 16) suggest that, after $1 \mathrm{~h}$ incubation, the PNM delivered Cm-6 was initially contained within the cell cortex of the cytoplasm, and did not reach the perinuclear region of the cytoplasm until $4 \mathrm{~h}$ incubation had elapsed. This was consistent with other reports of dye localisation following intracellular delivery with micelles (Sun et al. 2010; Stefancíkova et al. 2014), via endocytosis (Sharma and Sharma 1997). After $24 \mathrm{~h}$ incubation with PNM delivered $\mathrm{Cm}-6$, the $3 \mathrm{~T} 3$ cells displayed intense intracellular $\mathrm{Cm}-6$ fluorescence (Fig. 16), but it had remained principally outside of the cell nucleus. The nuclear envelope is a double layered bilayer membrane, as opposed to a single bilayer outer cell membrane (Smoyer and Jaspersen 2014), which may have prevented Cm-6 nuclear penetration (Zhao et al. 2011). The increasing intensity of $\mathrm{Cm}-6$ fluorescence observed (Fig. 16) over the 1-24 $\mathrm{h}$ incubation period, may also have been the result of a time-dependant release of Cm-6 from the MPC-DPA PNM core and intracellular endosomal environment, where Cm-6 fluorescence quenching may have occurred (Bae et al. 2003). Overall, the Fig. 16 Brightfield images indicated the 3T3 cells were healthy, and the fluorescence images suggested that successful, and rapid, intracellular MPC-DPA PNM mediated delivery of Cm-6 had been achieved.

\section{Intracellular fluorescence persistence of MPC-DPA PNM delivered $\mathrm{Cm}-6$}

Following confirmation of MPC-DPA PNM mediated Cm6 intracellular delivery (Fig. 16), subsequent investigation examined the persistence of the $\mathrm{Cm}-6$ fluorescence in both V79 and 3 T3 cells. It can be seen from Fig. 17 that as before, after $24 \mathrm{~h}$ incubation, designated $t=0$, there was clear PNM delivered intracellular Cm-6 fluorescence in the V79 and 3T3 cells. It was noted that at $t=0$ whilst the morphology of the 3T3 cells appeared healthy and normal, the V79 cells, in contrast, displayed irregular cell morphologies, which may have indicated sensitivity to the Cm6 , and would be consistent with the apparent $\mathrm{Cm}-6$ toxicity towards V79 cells seen in Figs. 11 and 12, and discussed earlier. Following $t=0$ the cells were washed, and then incubated in fresh cell medium for a further 24 and $48 \mathrm{~h}$, $t=24$ and $t=48$, respectively, and it can be seen in Fig. 17 that intracellular $\mathrm{Cm}-6$ fluorescence persisted in the V79 and 3T3 cells through to $t=48$. Although Cm-6 fluorescence persisted over time, there was also an associated reduction in fluorescence intensity as time elapsed, possibly resulting from exocytosis of the Cm-6 from the cells (Sun et al. 2010; Strobel et al. 2015), or a dilution effect of cellular division, which would be consistent with the apparent recovery of normal cell morphology by the 
Fig. 16 Confocal laser scanning microscopy images of $3 \mathrm{~T} 3$ cells incubated for 1,4 , and $24 \mathrm{~h}$ with $\mathrm{MPC}_{100}-\mathrm{DPA}_{100} \mathrm{Cm}$ 6 loaded PNM systems (PBS, $\mathrm{pH}$ 7.4), and control $\mathrm{Cm}-6$ systems (PBS, pH 7.4),

illustrating both the rapid $(1 \mathrm{~h})$ cellular uptake, and enhanced levels of Cm-6 uptake, achieved by the PNM Cm-6 system. Scale bar $=25 \mu \mathrm{m}$

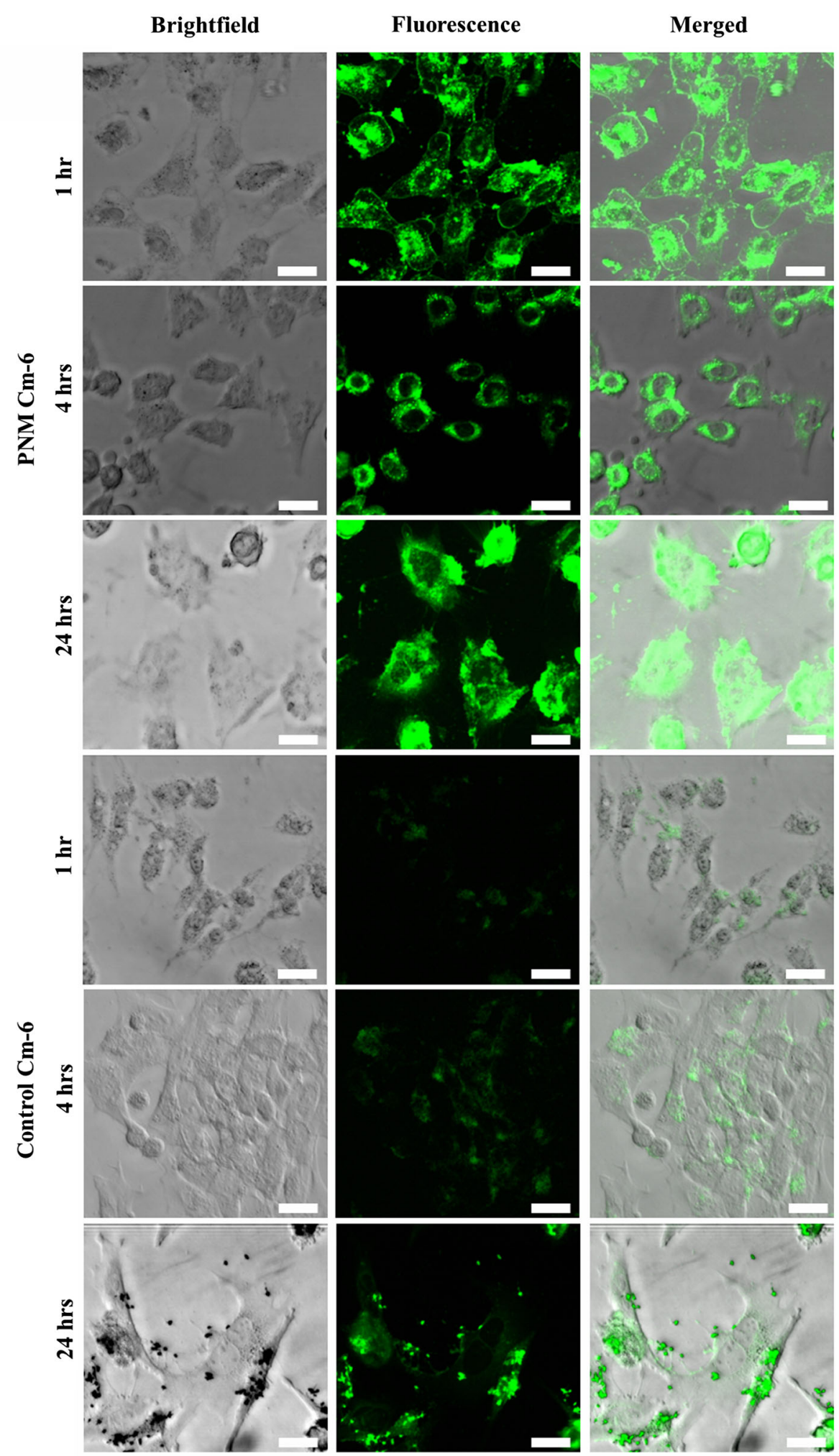

V79 cells seen at $t=48$. The 3T3 cells appeared more tolerant of the Cm-6, with normal cell morphology and extending pseudopodia visible at $t=48$ indicative of active cellular processes, which was in agreement with the lower toxicity seen in Fig. 13.
In summary, the results of the in vitro cellular toxicity assays (Figs. 11, 12, 13, 14) and the intracellular uptake studies (Figs. 15, 16, 17) indicate that $\mathrm{MPC}_{100}-\mathrm{DPA}_{100}$ PNM systems were of minimal cellular toxicity, and capable of rapid intracellular delivery, and therefore a good 

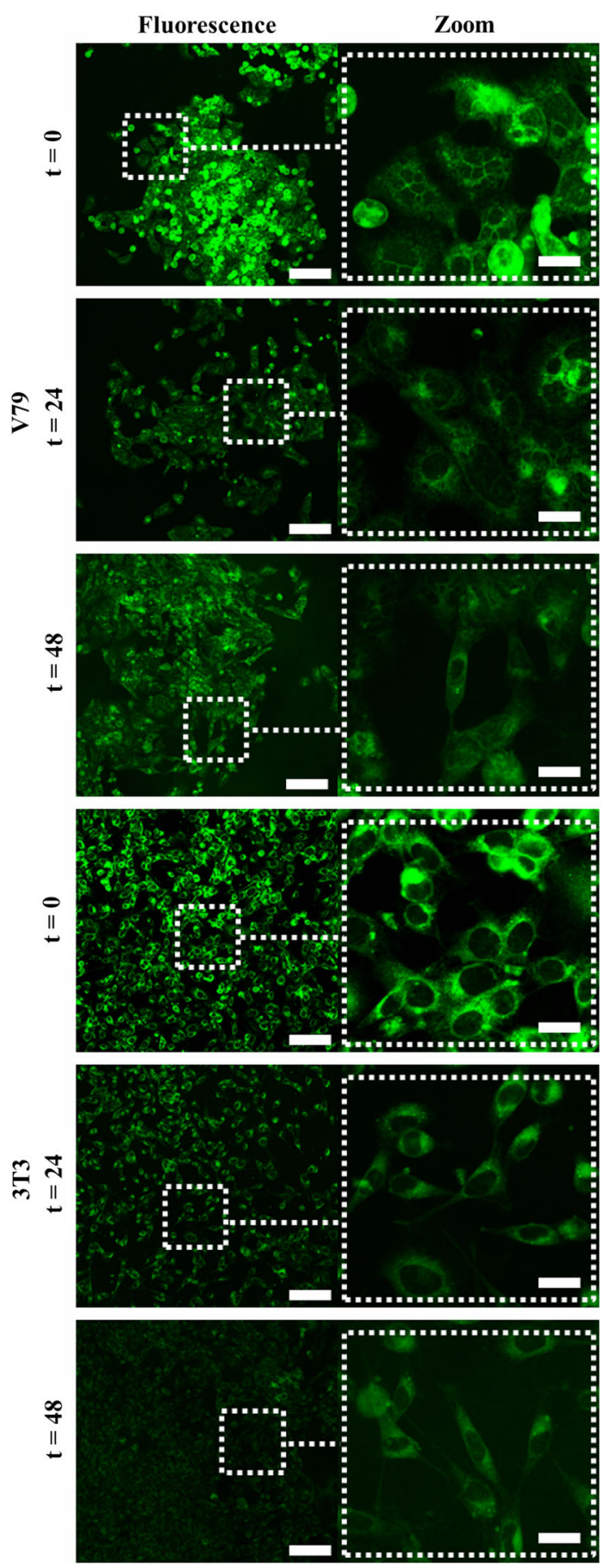

Fig. 17 Confocal laser scanning microscopy images of V79 and 3T3 cells incubated for $24 \mathrm{~h}$ with $\mathrm{MPC}_{100}-\mathrm{DPA}_{100} \mathrm{Cm}-6$ loaded PNM systems (PBS, pH 7.4), displaying the fluorescence seen after incubation $(t=0)$, and subsequent fluorescence persistence over 24 $(t=24)$ and $48(t=48)$ hours. Scale bars $=125$ and $25 \mu \mathrm{m}$ for fluorescence and zoom images respectively

candidate for live cell imaging applications, providing an appropriate choice of cellularly tolerated fluorophore is made, and thus potentially, theranostic nanomedicine (Cole and Holland 2015) applications.

\section{Conclusions}

In conclusion, this paper reports the synthesis, characterisation, in vitro cellular uptake kinetics, and nanoprecipitation of PC-based polymeric nanoparticle micelles (PNM) from the well-defined, and low polydispersity, diblock copolymer $\mathrm{MPC}_{100}-\mathrm{DPA}_{100}$, as confirmed by ${ }^{1} \mathrm{H}$ NMR and GPC analysis. It had previously been demonstrated that $\mathrm{MPC}_{100}-\mathrm{DPA}_{100}$ PNM systems were biocompatible, dilution, time, and thermally stable, $\mathrm{pH}$ stimuli responsive, and formed monodisperse nanoparticle micelles via nanoprecipitation (Salvage et al. 2005, 2015). Herein, this study has expanded upon the prior art to present in this paper the first report of considerable further novel data, including an improved GPC protocol, the apparent Cryo-stability properties of the MPC-DPA block copolymer relative to concentration, the concentration stable and controllable nanoprecipitation of monodisperse PNM with diameters of circa 65-70 nm, Cryo-SEM imaging of the PNM, the successful loading of the hydrophobic fluorophore Cm-6 as a model drug compound into the PNM, with loading efficiencies of circa $60 \%$, together with the rapid $(1 \mathrm{~h})$ intracellular uptake of $\mathrm{MPC}_{100}-\mathrm{DPA}_{100}$ PNM delivered Cm-6, with the resultant fluorescence persisting for $48 \mathrm{~h}$. These novel data and findings further strengthen the potential for MPC-DPA PNM systems to be developed for a range of nanoparticle-based applications including hydrophobic therapeutic delivery, diagnostics, and combined multifaceted theranostics, and thus of nanomedicine interest.

Acknowledgments The authors gratefully acknowledge Quorum Technologies Ltd for Cryo-SEM technical support, and Biocompatibles UK Ltd and The University of Brighton for provision of materials.

Open Access This article is distributed under the terms of the Creative Commons Attribution 4.0 International License (http:// creativecommons.org/licenses/by/4.0/), which permits unrestricted use, distribution, and reproduction in any medium, provided you give appropriate credit to the original author(s) and the source, provide a link to the Creative Commons license, and indicate if changes were made.

\section{References}

Adams JC, Gullick WJ (1989) Differences in phorbol-ester-induced down-regulation of protein kinase $\mathrm{C}$ between cell lines. Biochem J 257(3):905-911. doi:10.1042/bj2570905

Aliabadi HM, Elhasi S, Mahmud A, Gulamhusein R, Mahdipoor P, Lavasanifar A (2007) Encapsulation of hydrophobic drugs in polymeric micelles through co-solvent evaporation: the effect of solvent composition on micellar properties and drug loading. Int J Pharm 329:158-165. doi:10.1016/j.ijpharm.2006.08.018

Ansari RR, Nyeo SL (2012) Submicron particle size distributions by dynamic light scattering with non-negative least-squares algorithm. Chin J Phys 50(3):459-477. doi:10.6122/CJP 
Bae Y, Fukushima S, Harada A, Kataoka K (2003) Design of environment-sensitive supramolecular assemblies for intracellular drug delivery: polymeric micelles that are responsive to intracellular pH change. Angew Chem Int Ed 42(38):4640-4643. doi:10.1002/anie.200250653

Basak R, Bandyopadhyay R (2013) Encapsulation of hydrophobic drugs in pluronic F127 micelles: Effects of drug hydrophobicity, solution temperature, and pH. Langmuir 29(13):4350-4356. doi:10.1021/la304836e

Benoit GG, Naud CF, Simard MA, Astier AL (1997) Noninterference of cytochrome P4501A2 in the cytotoxicity of tacrine using genetically engineered V79 Chinese hamster cells for stable expression of the human or rat isoform and two human hepatocyte cell lines. Biochem Pharmacol 53(3):423-427. doi:10.1016/ S0006-2952(96)00713-7

Bilati U, Allemann E, Doelker E (2005) Development of a nanoprecipitation method intended for the entrapment of hydrophilic drugs into nanoparticles. Eur J Pharm Sci 24(1):67-75. doi:10.1016/j.ejps.2004.09.011

Bories-Azeau X, Armes SP (2002) Unexpected transesterification of tertiary amine methacrylates during methanolic ATRP at ambient temperature: a cautionary tale. Macromolecules 35(27):10241-10243. doi:10.1021/ma021388g

Bories-Azeau X, Armes SP, van den Haak HJW (2004) Facile synthesis of zwitterionic diblock copolymers without protecting group chemistry. Macromolecules 37(7):2348-2352. doi:10. 1021/ma035904u

Born SL, Caudill D, Smith BJ, Lehman-McKeeman LD (2000) In vitro kinetics of coumarin 3,4-epoxidation: application to species differences in toxicity and carcinogenicity. Toxicol Sci 58(1):23-31. doi:10.1093/toxsci/58.1.23

Boullier A, Friedman P, Harkewicz R, Hartvigsen K, Green SR, Almazan F, Dennis EA, Steinberg D, Witztum JL, Quehenberger O (2005) Phosphocholine as a pattern recognition ligand for CD36. J Lipid Res 46:969-976. http://www.jlr.org/content/46/5/ 969.long

Cao Z, Jiang S (2012) Super-hydrophilic zwitterionic poly(carboxybetaine) and amphiphilic non-ionic poly(ethylene glycol) for stealth nanoparticles. Nano Today 7(5):404-413. doi:10.1016/j. nantod.2012.08.001

Chu H, Liu N, Wang X, Jiao Z, Chen Z (2009) Morphology and in vitro release kinetics of drug-loaded micelles based on welldefined PMPC-b-PBMA copolymer. Int J Pharm 371:190-196. doi:10.1016/j.ijpharm.2008.12.033

Cole JT, Holland NB (2015) Multifunctional nanoparticles for use in theranostic applications. Drug Deliv Transl Res 5(3):295-309. doi:10.1007/s13346-015-0218-2

Colley HE, Hearnden V, Milagros AO, Cecchin D, Canton I, Madsen J, MacNeil S, Warren N, Hu K, McKeating JA, Armes SP, Murdoch C, Thornhill MH, Battaglia G (2014) Polymersomemediated delivery of combination anticancer therapy to head and neck cancer cells: 2D and 3D in vitro evaluation. Mol Pharm 11(4):1176-1188. doi:10.1021/mp400610b

Connell LS, Jones JR, Weaver JVM (2012) Transesterification of functional methacrylate monomers during alcoholic coppercatalyzed atom transfer radical polymerization: formation of compositional and architectural side products. Polym Chem 3:2735-2738. doi:10.1039/C2PY20280H

Coppola G, Fabbri P, Pallesi B, Bianchi U (1972) Salt effect on gel permeation chromatography of partially charged polymers. J Appl Polym Sci 16(11):2829-2834. doi:10.1002/app.1972. 070161109

Crucho CIC (2015) Stimuli-responsive polymeric nanoparticles for nanomedicine. ChemMedChem 10:24-38. doi:10.1002/cmdc. 201402290
Date PV, Samad A, Devarajan PV (2010) Freeze thaw: a simple approach for prediction of optimal cryoprotectant for freeze drying. AAPS PharmSciTech 11(1):304-313. doi:10.1208/ s12249-010-9382-3

Davda J, Labhasetwar V (2002) Characterization of nanoparticle uptake by endothelial cells. Int J Pharm 233:51-59. doi:10.1016/ S0378-5173(01)00923-1

Diaz G, Melis M, Batetta B, Anguis F, Falchi AM (2008) Hydrophobic characterization of intracellular lipids in situ by nile red red/yellow emission ratio. Micron 39(7):819-824. doi:10.1016/j.micron.2008.01.001

Drozdek S, Bazylinska U (2015) Biocompatible oil core nanocapsules as potential co-carriers of paclitaxel and fluorescent markers: preparation, characterization, and bioimaging. Colloid Polym Sci. doi:10.1007/s00396-015-3767-5

Du J, Tang Y, Lewis AL, Armes SP (2005) pH-sensitive vesicles based on a biocompatible zwitterionic diblock copolymer. J Am Chem Soc 127(51):17982-17983. doi:10.1021/ja0565141

Dubin PL, Koontz S, Wright KL (1977) Substrate-polymer interactions in liquid exclusion chromatography (GPC) in N,Ndimethylformamide. J Polym Sci Polym Chem 15(9):2047-2057. doi:10.1002/pol.1977.170150901

Edmondson S, Nguyen NT, Lewis AL, Armes SP (2010) Cononsolvency effects for surface-initiated poly(2-(methacryloyloxy)ethyl phosphorylcholine) brushes in alcohol/water mixtures. Langmuir 26(10):7216-7226. doi:10.1021/la904346j

Farokhzad OC, Langer R (2006) Nanomedicine: Developing smarter therapeutic diagnostic modalities. Adv Drug Deliv Rev 58:1456-1459. doi:10.1016/j.addr.2006.09.011

Fotakis G, Timbrell JA (2006) In vitro cytotoxicity assays: Comparison of LDH, neutral red, MTT and protein assay in hepatoma cell lines following exposure to cadmium chloride. Toxicol Lett 160(2):171-177. doi:10.1016/j.toxlet.2005.07.001

Franken NA, Rodermond HM, Stap J, Haveman J, van Bree C (2006) Clonogenic assay of cells in vitro. Nat Protoc 1:2315-2319. doi:10.1038/nprot.2006.339

Gao CY, Qiao X, Ma ZY, Wang ZG, Lu J, Tian JL, Xu JY, Yan SP (2012) Synthesis, characterization, DNA binding and cleavage, BSA interaction and anticancer activity of dinuclear zinc complexes. Dalton Trans 41:12220-122232. doi:10.1039/ C2DT31306E

Garcia KP, Zarschler K, Barbaro L, Barreto JA, O'Malley W, Spiccia L, Stephan H, Graham B (2014) Zwitterionic-coated "stealth" nanoparticles for biomedical applications: recent advances in countering biomolecular corona formation and uptake by the mononuclear phagocyte system. Small 10(13):2516-2529. doi: $10.1002 / \mathrm{smll} .201303540$

Giacomelli C, Le Men L, Borsali R, Lai-Kee-Him J, Brisson A, Armes SP, Lewis AL (2006) Phosphorylcholine-based pHresponsive diblock copolymer micelles as drug delivery vehicles: light scattering, electron microscopy, and fluorescence experiments. Biomacromolecules 7(3):817-828. doi:10.1021/ bm0508921

Goda T, Watanabe J, Takai M, Ishihara K (2006) Water structure and improved mechanical properties of phospholipid polymer hydrogel with phosphorylcholine centred intermolecular cross-linker. Polymer 47(4):1390-1396. doi:10.1016/j.polymer.2005.12.043

Greenspan P, Mayer EP, Fowler SD (1985) Nile red: a selective fluorescent stain for intracellular lipid droplets. J Cell Biol 100(3):965-973. doi:10.1083/jcb.100.3.965

Gref R, Yoshiharu M, Peracchia MT, Trubetskoy V, Torchilin V, Langer R (1994) Biodegradable long-circulating polymeric nanospheres. Science 263:1600-1603. doi:10.1126/science.8128245

Hann ND (1977) Effects of lithium bromide on the gel-permeation chromatography of polyester-based polyurethanes in 
dimethylformamide. J Polym Sci Polym Chem 15(6):1331-1339. doi:10.1002/pol.1977.170150604

Hayward JA, Chapman D (1984) Biomembrane surfaces as models for polymer design: the potential for haemocompatibility. Biomaterials 5:135-142. doi:10.1016/0142-9612(84)90047-4

Ho KS, Shoichet MS (2013) Design considerations of polymeric nanoparticle micelles for chemotherapeutic delivery. Curr Opin Chem Eng 2(1):53-59. doi:10.1016/j.coche.2013.01.003

Issman L, Talmon Y (2012) Cryo-SEM specimen preparation under controlled temperature and concentration conditions. J Microsc 246(1):60-69. doi:10.1111/j.1365-2818.2011.03587.x

Kaszuba M, McKnight D, Connah MT, McNeil-Watson FK, Nobbmann U (2008) Measuring sub nanometre sizes using dynamic light scattering. J Nanopart Res 10(5):823-829. doi:10.1007/ s11051-007-9317-4

Kataoka K, Harada A, Nagasaki Y (2001) Block copolymer micelles for drug delivery: design, characterization and biological significance. Adv Drug Deliv Rev 47(1):113-131. doi:10.1016/S0169409X(00)00124-1

Kawasaki ES, Player A (2005) Nanotechnology, nanomedicine, and the development of new, effective therapies for cancer. Nanomed Nanotechnol Biol Med 1:101-109. doi:10.1016/j. nano.2005.03.002

Khemtong C, Kessinger CW, Gao J (2009) Polymeric nanomedicine for cancer MR imaging and drug delivery. Chem Commun 84:3477-3640. doi:10.1039/b821865j

Kontogiorgis C, Detsi A, Hadjipavlou-Litina D (2012) Coumarinbased drugs: a patent review (2008-present). Expert Opin Ther Pat 22(4):437-454. doi:10.1517/13543776.2012.678835

Kristoffersen AS, Erga SR, Hamre B, Frette O (2014) Testing fluorescence lifetime standards using two-photon excitation and time-domain instrumentation: rhodamine $\mathrm{B}$, coumarin 6 and lucifer yellow. J Fluoresc 24(4):1015-1024. doi:10.1007/ s10895-014-1368-1

Kronberg B, Castas M, Silvestonti R (1994) Understanding the hydrophobic effect. J Dispers Technol 15(3):333-351. doi:10. 1080/01932699408943561

Lake BG, Grasso P (1996) Comparison of the hepatotoxicity of coumarin in the rat, mouse, and syrian hamster: a dose and time response study. Toxicol Sci 34(1):105-117. doi:10.1093/toxsci/ 34.1.105

Laskar P, Biswajit S, Ghosh SK, Dey J (2015) PEG based random copolymer micelles as drug carriers: the effect of hydrophobe content on drug solubilisation and cytotoxicity. RSC Adv 5:16265-16276. doi:10.1039/C4RA11479E

Le TL, Joseph SR, Yap AS, Stow JL (2002) Protein kinase C regulates endocytosis and recycling of E-cadherin. Am J Physiol Cell Physiol 283(2):C489-C499. doi:10.1152/ajpcell.00566. 2001

Lee RS, Chen WH (2010) Synthesis of amphiphilic temperaturesensitive poly(N-isopropylacrylamide)-block-poly(tetramethylene carbonate) block copolymers and micellar characterization. Polym Int 60(2):255-263. doi:10.1002/pi.2937

Lee HS, Lee HJ, Suh HJ (2011) Silk protein hydrolysate increases glucose uptake through up-regulation of GLUT 4 and reduces the expression of leptin in 3T3-L1 fibroblast. Nutr Res 31(12):937-943. doi:10.1016/j.nutres.2011.09.009

Lepeltier E, Bourgaux C, Couvreur P (2014) Nanoprecipitation and the "Ouzo effect": application to drug delivery devices. Adv Drug Deliv Rev 71:86-97. doi:10.1016/j.addr.2013.12.009

Lewis AL (2000) Phosphorylcholine-based polymers and their use in the prevention of biofouling. Colloids Surf B 18:261-275. doi:10.1016/S0927-7765(99)00152-6

Lewis AL, Hughes PD, Kirkwood LC, Leppard SW, Redman RP, Tolhurst LA, Stratford PW (2000) Synthesis and characterisation of phosphorylcholine based polymers useful for coating blood filtration devices. Biomaterials 21(18):1847-1859. doi:10.1016/ S0142-9612(00)00055-7

Li YG, Shi PJ, Zhou Y, Pan CY (2004) Synthesis and characterization of block comb-like copolymers P(A-MPEO)-block-PSt. Polym Int 53(3):349-354. doi:10.1002/pi.1407

Licciardi M, Tang Y, Billingham NC, Armes SP, Lewis AL (2005) Synthesis of novel folic acid-functionalized biocompatible block copolymers by atom transfer radical polymerization for gene delivery and encapsulation of hydrophobic drugs. Biomacromolecules 6(2):1085-1096. doi:10.1021/bm049271i

Licciardi M, Giammona G, Du J, Armes SP, Tang Y, Lewis AL (2006) New folate-functionalized biocompatible block copolymer micelles as potential anti-cancer drug delivery systems. Polymer 47(9):2946-2955. doi:10.1016/j.polymer.2006.03.014

Licciardi M, Craparo EF, Giammona G, Armes SP, Tang Y, Lewis AL (2008) In vitro biological evaluation of folate-functionalised block copolymer micelles for selective anti-cancer drug delivery. Macromol Biosci 8(7):615-626. doi:10.1002/mabi.200800009

Lin JJ, Chen JS, Huang SJ, Ko JH, Wang YM, Chen TL, Wang LF (2009) Folic acid-Pluronic F127 magnetic nanoparticle clusters for combined targeting, diagnosis, and therapy applications. Biomaterials 30(28):5114-5124. doi:10.1016/j.biomaterials.2009.06.004

Lin W, Nie S, Xiong D, Guo X, Wang J, Zhang L (2014) pHresponsive micelles based on (PCL) ${ }_{2}$ (PDEA-b-PPEGMA $)_{2}$ miktoarm polymer: controlled synthesis, characterization, and application as anticancer drug carrier. Nanoscale Res Lett 9:243. doi:10.1186/1556-276X-9-243

Liu J, Huang Y, Kumar A, Tan A, Jin S, Mozhi A, Liang XJ (2014) $\mathrm{pH}$-sensitive nano-systems for drug delivery in cancer therapy. Biotechnol Adv 32(4):693-710. doi:10.1016/j.biotechadv.2013. 11.009

Lobb EJ, Ma I, Billingham NC, Armes SP (2001) Facile synthesis of well-defined, biocompatible phosphorylcholine-based methacrylate copolymers via atom transfer radical polymerization at $20{ }^{\circ} \mathrm{C}$. J Am Chem Soc 123(32):7913-7914. doi:10.1021/ ja003906d

Locatelli E, Franchini MC (2012) Biodegradable PLGA-b-PEG polymeric nanoparticles: synthesis, properties, and nanomedical applications as drug delivery system. J Nanopart Res 14:1316. doi:10.1007/s11051-012-1316-4

Logie J, Owen SC, McLaughlin CK, Shoichet MS (2014) PEG-graft density controls polymeric nanoparticle micelle stability. Chem Mater 26(9):2847-2855. doi:10.1021/cm500448x

Lomas H, Massignani M, Abdullah KA, Canton I, Lo Presti C, MacNeil S, Du J, Blanazs A, Madsen J, Armes SP, Lewis AL, Battaglia G (2008) Non-cytotoxic polymer vesicles for rapid and efficient intracellular delivery. Faraday Discuss 139:143-159. doi:10.1039/B717431D

Lomas H, Du J, Canton I, Madsen J, Warren N, Armes SP, Lewis AL, Battaglia G (2010) Efficient encapsulation of plasmid DNA in pH-sensitive PMPC-PDPA polymersomes: study of the effect of PDPA block length on copolymer-DNA binding affinity. Macromol Biosci 10(5):513-530. doi:10.1002/mabi.201000083

Lucyanna BB, Gelen R, Merce C, Laia R, Carmen LI, de Alfons LM, Olga L (2011) Structural versatility of bicellar systems and their possibilities as colloidal carriers. Pharmaceutics 3(3):636-664. doi:10.3390/pharmaceutics3030636

Ma IY, Tang Y, Billingham NC, Armes SP, Lewis AL, Lloyd AW, Salvage JP (2003) Well-defined biocompatible block copolymers via atom transfer radical polymerisation of 2-methacryloyloxyethyl phosphorylcholine in protic media. Macromolecules 36:3475-3484. doi:10.1021/ma021762c

Madsen J, Warren NJ, Armes SP, Lewis AL (2011) Synthesis of rhodamine 6G-based compounds for the ATRP synthesis of fluorescently labeled biocompatible polymers. Biomacromolecules 12(6):2225-2234. doi:10.1021/bm200311s 
Madsen J, Canton I, Warren NJ, Themistou E, Blanazs A, Ustbast B, Tian X, Pearson R, Battaglia G, Lewis AL, Armes SP (2013) Nile blue-based nanosized $\mathrm{pH}$ sensors for simultaneous far-red and near-infrared live bioimaging. $\mathrm{J}$ Am Chem Soc 135(39):14863-14870. doi:10.1021/ja407380t

Maeda H (2001) The enhanced permeability and retention (EPR) effect in tumor vasculature: the key role of tumor-selective macromolecular drug targeting. Adv Enzyme Regul 41:189-207. doi:10.1016/S0065-2571(00)00013-3

Mahon J, Zhu S (2008) Interactions of poly(2-methacryloyloxyethyl phosphorylcholine) with various salts studied by size exclusion chromatography. Colloid Polym Sci 286(12):1443-1454. doi:10. 1007/s00396-008-1915-x

Marzio LD, Marianecci C, Cinque B, Nazzarri M, Cimini AM, Cristiano L, Cifone MG, Alhaique F, Carafa M (2008) pHsensitive non-phospholipid vesicle and macrophage-like cells: binding, uptake and endocytotic pathway. Biochim et Biophys Acta 1178(12):2749-2756. doi:10.1016/j.bbamem.2008.07.029

Massignani M, Canton I, Sun T, Hearnden V, MaCNeil S, Blanazs A, Armes SP, Lewis A, Battaglia G (2010) Enhanced fluorescence imaging of live cells by effective cytosolic delivery of probes. PLoS One 5(5):e10459. doi:10.1371/journal.pone.0010459

Maxfield J, Shepherd IW (1975) Confirmation of poly(ethylene oxide) in the solid state, melt and solution measured by Raman scattering. Polymer 16(7):505-509. doi:10.1016/0032-3861(75) 90008-7

Meyer EE, Rosenberg KJ, Israelachvili J (2006) Recent progress in understanding hydrophobic interactions. Proc Natl Acad Sci USA 103(43):15739-15746. doi:10.1073/pnas.0606422103

Morisaku T, Watanabe J, Konno T, Takai M, Ishihara K (2008) Hydration of phosphorylcholine groups attached to highly swollen polymer hydrogels studied by thermal analysis. Polymer 49(21):4652-4657. doi:10.1016/j.polymer.2008.08.025

Mosmann T (1983) Rapid colorimetric assay for cellular growth and survival: application to proliferation and cytotoxicity assays. J Immunol Methods 65:55-63. doi:10.1016/0022-1759(83) 90303-4

Nikzad S, Hashemi B (2014) MTT assay instead of the clonogenic assay in measuring the response of cells to ionizing radiation. J Radiobiol 1(1):3-8. doi: 10.15171/jrb.2014.02

Pearson RT, Warren NJ, Lewis AL, Armes SP, Battaglia G (2013) Effect of $\mathrm{pH}$ and temperature on PMPC-PDPA copolymer selfassembly. Macromolecules 46(4):1400-1407. doi:10.1021/ ma302228m

Pegoraro C, Cecchin D, Gracia LS, Warren N, Madsen J, Armes SP, Lewis A, Macneil S, Battaglia G (2013) Enhanced drug delivery to melanoma cells using PMPC-PDPA polymersomes. Cancer Lett 334(2):328-337. doi:10.1016/j.canlet.2013.02.007

Pegoraro C, Cecchin D, Madsen J, Warren N, Armes SP, MacNeil S, Lewis A, Battaglia G (2014) Translocation of flexible polymersomes across pores at the nanoscale. Biomater Sci 2:680-692. doi:10.1039/C3BM60294J

Penfold NJW, Lovett JR, Warren NJ, Verstraete P, Smets J, Armes SP (2015) pH-Responsive non-ionic diblock copolymers: protonation of a morpholine end-group induces an order-order transition. Polym Chem. doi:10.1039/C5PY01510C

Petritis K, Elfakir C, Dreux M (2002) A comparative study of commercial liquid chromatographic detectors for the analysis of underivatized amino acids. J Chromatogr A 961(1):9-21. doi:10. 1016/S0021-9673(02)00377-1

Rivolta I, Panariti A, Lettiero B, Sesana S, Gasco P, Gasco MR, Masserini M, Miserocchi G (2011) Cellular uptake of coumarin6 as a model drug loaded in solid lipid nanoparticles. J Physiol Pharmacol 62(1):45-53. http://www.ncbi.nlm.nih.gov/pubmed/ 21451209
Robinson KL, Weaver JVM, Armes SP, Marti ED, Meldrum FC (2002) Synthesis of controlled-structure sulfate-based copolymers via atom transfer radical polymerisation and their use as crystal habit modifiers for BaSO4. J Mater Chem 12:890-896. doi:10.1039/B200348C

Rubin H, Yao A, Chow M (1995) Neoplastic development: paradoxical relation between impaired cell growth at low population density and excessive growth at high density. Proc Natl Acad Sci USA 92(17):7734-7738. http://www.ncbi.nlm.nih.gov/pmc/ articles/PMC41220/

Ruiz-Perez L, Madsen J, Themistou E, Gaitzsch J, Messager L, Armes SP, Battaglia G (2015) Nanoscale detection of metallabeled copolymers in patchy polymersomes. Polym Chem 6:2065-2068. doi:10.1039/C4PY01508H

Sahay G, Alakhova DY, Kabanov AV (2010) Endocytosis of nanomedicines. J Controlled Release 145:182-195. doi:10. 1016/j.jconrel.2010.01.036

Sahoo SK, Parveen S, Panda JJ (2007) The present and future of nanotechnology in human health. Nanomed Nanotechnol Biol Med 3:20-31. doi:10.1016/j.nano.2006.11.008

Salvage JP, Rose SF, Phillips GJ, Hanlon GW, Lloyd AW, Ma IY, Armes SP, Billingham NC, Lewis AL (2005) Novel biocompatible phosphorylcholine-based self-assembled nanoparticles for drug delivery. J Controlled Release 104:259-270. doi:10.1016/j. jconrel.2005.02.003

Salvage JP, Thom C, Lewis AL, Phillips GJ, Lloyd AW (2015) Nanoprecipitation of polymeric nanoparticle micelles based on 2-methacryloyloxyethyl phosphorylcholine (MPC) with 2-(diisopropylamino)ethyl methacrylate (DPA), for intracellular delivery applications. J Mater Sci Mater Med 26:150. doi:10. 1007/s10856-015-5480-9

Schubert MA, Muller-Goymann CC (2003) Solvent injection as a new approach for manufacturing lipid nanoparticles: evaluation of the method and process parameters. Eur $\mathrm{J}$ Pharm Biopharm 55(1):125-131. doi:10.1016/S0939-6411(02)00130-3

Sezgin Z, Yuksel N, Baykara T (2006) Preparation and characterization of polymeric micelles for solubilization of poorly soluble anticancer drugs. Eur J Pharm Biopharm 64(3):261-268. doi:10. 1016/j.ejpb.2006.06.003

Sharma A, Sharma US (1997) Liposomes in drug delivery: progress and limitations. Int J Pharm 154:123-140. doi:10.1016/S03785173(97)00135-X

Sharma PK, Reilly MJ, Jones DN, Robinson PM, Bhatia SR (2008) The effect of pharmaceuticals on the nanoscale structure of PEOPPO-PEO micelles. Colloids Surf B 61(1):53-60. doi:10.1016/j. colsurfb.2007.07.002

Shikata T, Takahashi R, Sakamoto A (2006) Hydration of poly(ethylene oxide)s in aqueous solution as studied by dielectric relaxation measurements. J Phys Chem B 110(18): 8941-8945. doi:10.1021/jp060356i

Shiraishi K, Kawano K, Minowa T, Maitani Y, Yokoyama M (2009) Preparation and in vivo imaging of PEG-poly(L-lysine)-based polymeric micelle MRI contrast agents. J Controlled Release 136:14-20. doi:10.1016/j.jconrel.2009.01.010

Sieuwerts AM, Klijn JGM, Peters HA, Foekens JA (1995) The MTT tetrazolium salt assay scrutinized: How to use this assay reliably to measure metabolic activity of cell cultures in vitro for the assessment of growth characteristics, IC50-values and cell survival. Clin Chem Lab Med 33(11):813-824. doi:10.1515/ cclm.1995.33.11.813

Singh R, Lillard JW (2009) Nanoparticle-based targeted drug delivery. Exp Mol Pathol 86(3):215-223. doi:10.1016/j.yexmp. 2008.12.004

Sivak A, Rudenko L, Teague LG (1982) Variations among species and cell types in the effects of caffeine on mutagen-induced

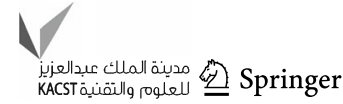


cytotoxicity and postreplication repair of DNA. Environ Mutagen 4(2):143-162. doi:10.1002/em.2860040206

Smoyer CJ, Jaspersen SL (2014) Breaking down the wall: the nuclear envelope during mitosis. Curr Opin Cell Biol 26:1-9. doi:10. 1016/j.ceb.2013.08.002

Snipstad S, Westrom S, Morch Y, Afadzi M, Aslund AK, Davies CL (2014) Contact-mediated intracellular delivery of hydrophobic drugs from polymeric nanoparticles. Cancer Nanotechnol 5:8. doi:10.1186/s12645-014-0008-4

Song YS, Adler D, Xu F, Kayaalp E, Nureddin A, Anchan RM, Maas RL, Demirci U (2010) Vitrification and levitation of a liquid droplet on liquid nitrogen. PNAS 107(10):4596-4600. doi:10. 1073/pnas.0914059107

Stefancíkova L, Porcel E, Eustache P, Li S, Salado D, Marco S, Guerquin-Kern JL, Refregiers M, Tillement O, Lux F, Lacombe $S$ (2014) Cell localisation of gadolinium-based nanoparticles and related radiosensitising efficacy in glioblastoma cells. Cancer Nanotechnol 5(1):6. doi:10.1186/s12645-014-0006-6

Stenzel MH, Barner-Kowollik C, Davis TP, Dalton HM (2004) Amphiphilic block copolymers based on poly(2-acryloyloxyethyl phosphorylcholine) prepared via RAFT polymerisation as biocompatible nanocontainers. Macromol Biosci 4(4):445-453. doi:10.1002/mabi.200300113

Strobel C, Oehring H, Herrmann R, Forster M, Reller A, Hilger I (2015) Fate of cerium dioxide nanoparticles in endothelial cells: exocytosis. J Nanopart Res 17:206. doi:10.1007/s11051-0153007-4

Sun X, Li F, Wang Y, Liang W (2010) Cellular uptake and elimination of lipophilic drug delivered by nanocarriers. Pharmazie 65:737-742. doi:10.1691/ph.2010.0099

Takakura Y, Mahato RI, Hashida M (1998) Extravasation of macromolecules. Adv Drug Deliv Rev 34:93-108. doi:10.1016/ S0169-409X(98)00006-4

Tan HS, Ritschel WA, Sanders PRA (1976) Determination of coumarin and umbelliferone mixtures in whole blood by spectrophotofluorometry. J Pharm Sci 65(1):30-33. doi:10. 1002/jps.2600650104

Tanford C (1974) Thermodynamics of micelle formation: prediction of micelle size and size distribution. Proc Natl Acad Sci USA 71(5):1811-1815. http://www.jstor.org/stable/63530

Tang R, Ji W, Panus D, Palumbo RN, Wang C (2011) Block copolymer micelles with acid-labile ortho ester side-chains: Synthesis, characterization, and enhanced drug delivery to human glioma cells. J Controlled Release 151(1):18-27. doi:10.1016/j.jconrel.2010.12.005
Torchilin VP (2002) PEG-based micelles as carriers of contrast agents for imaging modalities. Adv Drug Deliv Rev 54:235-252. doi:10.1016/S0169-409X(02)00019-4

Torre LA, Bray F, Siegel RL, Ferlay J, Lortet-Tieulent J, Jemal A (2015) Global cancer statistics, 2012. CA Cancer J Clin 65:87-108. doi:10.3322/caac. 21262

Trapani A, Sitterberg J, Bakowsky U, Kissel T (2009) The potential of glycol chitosan nanoparticles as carrier for low water soluble drugs. Int J Pharm 375:97-106. doi:10.1016/j.ijpharm.2009.03. 041

Tu S, Chen YW, Qiu YB, Zhu K, Luo XL (2011) Enhancement of cellular uptake and antitumor efficiencies of micelles with phosphorylcholine. Macromol Biosci 11(10):1416-1425. doi:10. 1002/mabi.201100111

Wang XS, Armes SP (2000) Facile atom transfer radical polymerization of methyoxy-capped oligo(ethylene glycol) metharcylate in aqueous media at ambient temperature. Macromolecules 33(18):6640-6647. doi:10.1021/ma000671h

Woodbury DJ, Richardson ES, Grigg AW, Welling RD, Knudson BH (2006) Reducing liposome size with ultrasound: bimodal size distributions. J Liposome Res 16(1):57-80. doi:10.1080/ 08982100500528842

Yamada H, Hasegawa Y, Imai H, Takayama Y, Sugihara F, Matsuda T, Tochio H, Shirakawa M, Sando S, Kimura Y, Toshimitsu A, Aoyama Y, Kondo T (2015) Magnetic resonance imaging of tumor with a self-traceable phosphorylcholine polymer. J Am Chem Soc 137(2):799-806. doi:10.1021/ja510479v

Yu H, Yonglong Z, Lei J, Qi Y, Xinyu H, Lingli C, Zhiwen Z, Wangwen G, Yaping L (2013) Induction of apoptosis in nonsmall cell lung cancer by down regulation of MDM2 using $\mathrm{pH}-$ responsive PMPC-b-PDPA/siRNA complex nanoparticles. Biomaterials 34:2738-2747. doi:10.1016/j.biomaterials.2012.12.042

Yusa S, Fukuda K, Yamamoto T, Ishihara K, Morishima Y (2005) Synthesis of well-defined amphiphilic block copolymers having phospholipid polymer sequences as a novel biocompatible polymer micelle reagent. Biomacromolecules 6(2):663-670. doi:10.1021/bm0495553

Zhang H, Zhao L, Chu L, Han X, Zhai G (2014) Preparation, optimization, characterization and cytotoxicity in vitro of baicalin-loaded mixed micelles. J Colloid Interface Sci 434:40-47. doi:10.1016/j.jcis.2014.07.045

Zhao F, Zhao Y, Liu Y, Chang X, Chen C, Zhao Y (2011) Cellular uptake, intracellular trafficking, and cytotoxicity of nanomaterials. Small 7(10):1322-1337. doi:10.1002/smll.201100001 